\title{
What is new since the last (1999) Canadian Asthma Consensus Guidelines?
}

Louis-Philippe Boulet MD FRCPC ${ }^{1}$, Tony R Bai MD FRCPC ${ }^{2}$, Allan Becker MD FRCPC ${ }^{3}$, Denis Bérubé MD FRCPC ${ }^{4}$, Robert Beveridge MD FRCPC ${ }^{5}$, Dennis M Bowie MD ${ }^{6}$, Kenneth R Chapman MD FRCPC ${ }^{7}$, Johanne Côté $M^{1}{ }^{1}$, Donald Cockcroft MD FRCPC ${ }^{8}$, Francine M Ducharme MD ${ }^{4}$, Pierre Ernst MD FRCPC ${ }^{4}$, J Mark FitzGerald MD FRCPC ${ }^{2}$, Thomas Kovesi $\mathrm{MD}^{9}$, Richard V Hodder MD ${ }^{9}$, Paul O'Byrne $\mathrm{MD}^{10}$, Brian Rowe MD MSc CFPC-EM ${ }^{3}$, Malcolm R Sears MBChB FRCPC ${ }^{10}, F$ Estelle R Simons MD $^{3}$, Sheldon Spier MD ${ }^{11}$

${ }^{1}$ Sainte-Foy, Québec, ${ }^{2}$ Vancouver, British Columbia, ${ }^{3}$ Winnipeg, Manitoba, ${ }^{4}$ Montréal, Québec, ${ }^{5}$ Saint-John, New Brunswick, ${ }^{6}$ Halifax, Nova Scotia, ${ }^{7}$ Toronto, Ontario, ${ }^{8}$ Saskatoon, Saskatchewan, ${ }^{9}$ Ottawa, Ontario, ${ }^{10}$ Hamilton, Ontario, ${ }^{11}$ Calgary, Alberta

L-P Boulet, TR Bai, A Becker, et al. What is new since the last (1999) Canadian Asthma Consensus Guidelines? Can Respir J 2001;8(Suppl A): 5A-27A.

The objective of the present document is to review the impact of new information on the recommendations made in the last (1999) Canadian Asthma Consensus Guidelines. It includes relevant published studies and observations or comments regarding what are considered to be the main issues in asthma management in children and adults in office, emergency department, hospital and clinical settings. Asthma is still insufficiently controlled in a large number of patients, and practice guidelines need to be integrated better with current care. This report re-emphasises the need for the following: objective measures of airflow obstruction to confirm the diagnosis of asthma suggested by the clinical evaluation; identification of contributing factors; and the establishment of a treatment plan to rapidly obtain and maintain optimal asthma control according to specific criteria. Recent publications support the essential role of asthma education and environmental control in asthma management. They further support the role of inhaled corticosteroids as the mainstay of anti-inflammatory therapy of asthma, and of both long acting beta $_{2}$-agonists and leukotriene antagonists as effective means to improve asthma control when inhaled corticosteroids are insufficient. New developments, such as combination therapy, and recent major trials, such as the Children's Asthma Management Project (CAMP) study, are discussed.
Principes directeurs du consensus canadien sur l'asthme : quoi de neuf?

RÉSUMÉ : Le présent document vise à passer en revue l'incidence de nouveaux éléments sur les recommandations formulées dans le dernier rapport du consensus canadien sur l'asthme, paru en 1999. Le document fait état d'études publiées ainsi que d'observations ou de commentaires pertinents concernant les principaux aspects du traitement de l'asthme chez les enfants et les adultes, et ce, autant en cabinet qu' au service des urgences ou en milieu clinique ou hospitalier. Bon nombre de patients souffrent encore d'asthme non suffisamment maîtrisé, et il importe que les principes directeurs soient mieux intégrés dans la pratique actuelle. Ainsi est réaffirmée la nécessité de respecter les principes suivants : les mesures objectives d'obstruction à l'écoulement de l'air pour confirmer le diagnostic évoqué par l'évaluation clinique, l'identification des facteurs favorisants et l'élaboration d'un plan de traitement permettant d'atteindre rapidement une maîtrise optimale et soutenue de l'asthme selon certains critères bien définis. Des publications parues récemment confirment le rôle essentiel de l'éducation du patient et de la qualité de l'environnement dans le traitement de l'asthme. De plus, elles étayent le rôle des corticostérö̈des en aérosol comme composant principal du traitement anti-inflammatoire de l'asthme ainsi que des agonistes bêta $a_{2}$ à action prolongée et des antagonistes des leucotriènes comme compléments aux stéroïdes lorsque ceux-ci s'avèrent plus ou moins efficaces. Il sera aussi question des derniers progrès, comme la polythérapie, et des principaux essais menés récemment, comme le Children's Asthma Management Project (CAMP).

Key Words: Asthma guidelines; Asthma management; Asthma treatment; Consensus guidelines

Correspondence: Dr Louis-Philippe Boulet, Hôpital Laval, 2725 chemin Sainte-Foy, Sainte-Foy, Québec G1V 4G5. Telephone 418-656-4747, fax 418-656-4762,e-mail lpboulet@med.ulaval.ca 


\section{INTRODUCTION \\ Louis-Philippe Boulet}

In May 1998, a group of adult and pediatric respirologists, allergists, emergency physicians, pediatricians and family physicians met to review Canadian asthma consensus guidelines. A detailed version of the guidelines and both French and English summaries were published in the Canadian Medical Association Journal in November 1999 (1), and are available on a Web site (http://www.asthmaguidelines.com). Recommendations regarding asthma management were based on a combination of consensus opinion and interpretation of the most current evidence available, graded according to the Canadian Medical Association's "guidelines for guidelines" (2).

Given the complicated process required to establish guidelines (consensus conferences, detailed review of new information and publication following appropriate peer review), any published guidelines run the risk of being out of date soon after distribution. The need for ongoing review of evidence and validation of randomized clinical trial results makes the maintenance of guidelines a major challenge. The present document is an attempt to review the impact of new information on the recommendations made in the last Canadian asthma guidelines. This includes relevant published studies, and observations or comments from clinicians regarding issues considered to have been inadequately addressed. We also added comments and answers to questions received from different sources about the guidelines, and indicated whether current recommendations should be modified or the level of evidence changed for any of the previous guidelines. Finally, we thought it would be of interest to discuss new issues and considerations for the future, and to provide an update on the implementation process for the 1999 guidelines. Thus, the present document is not a new set of guidelines and does not replace the 1999 document, but we think that it will be a useful review for clinicians and will stress important aspects of the previous consensus.

\section{What is asthma?}

The following definition of asthma was provided in the 1999 document:

Asthma is characterized by paroxysmal or persistent symptoms such as dyspnea, chest tightness, wheezing, sputum production and cough associated with variable airflow limitation and a variable degree of airway hyper-responsiveness (AHR) to endogenous or exogenous stimuli. Inflammation and its resultant effects on airway structure are considered the main mechanisms leading to the development and maintenance of asthma (1).

The definition remains valid; both airway inflammation and structural changes are still considered important in the development of clinical manifestations of asthma.

There is little doubt that most cases of asthma occur as a result of environmental effects on the airways that trigger a
TABLE 1

Initial asthma treatment

1. Confirm diagnosis, evaluate symptoms, measure pulmonary function tests, assess environment and other contributing factors, and initate education

2. Medication

- If symptoms are infrequent and expiratory flows are normal, a beta2-agonist should be used on demand

- If a beta2-agonist is needed more than three times/week or if lung function is abnormal, an inhaled corticosteroid, equivalent to beclomethasone with a chlorofluorocarbon as a propellant, 400 to $1000 \mu \mathrm{g} /$ day is usually the preferred next step

- If symptoms are frequent, and expiratory flows and/or forced expiratory volume in $1 \mathrm{~s}$ are less than $60 \%$ of predicted or optimal values, initial therapy with prednisone should be considered

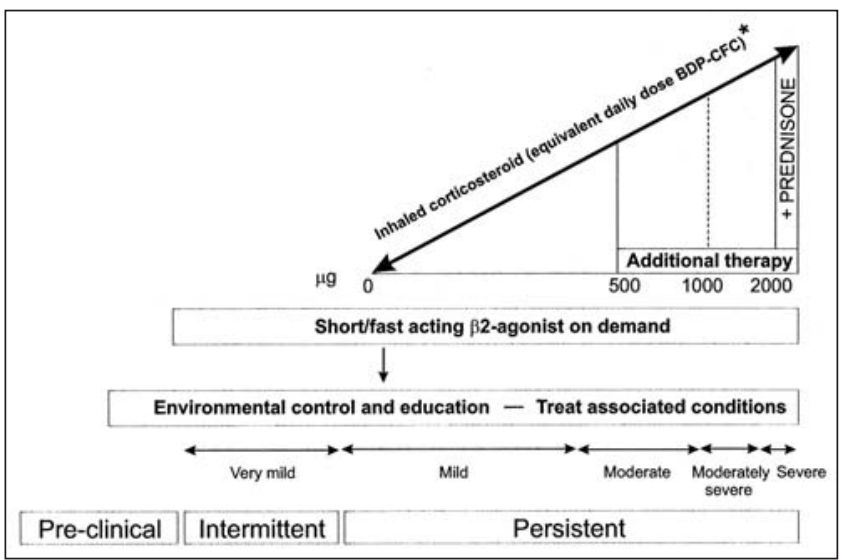

Figure 1) Maintenance asthma treatment. *Or leukotriene receptor antagonist if patient cannot or will not use inhaled corticosteroids. Adapted with permission from reference 1. BDP-CFC Beclomethasone-chlorofluorocarbon

series of modifications of the immune system in genetically predisposed individuals. In other cases, asthma may develop after toxic exposures (eg, high level irritant-induced occupational asthma). Regardless of the cause of asthma, there are a large number of chemicals, allergens and infectious agents that trigger airway inflammation and may contribute to the development of AHR. An increasing number of abnormalities in certain genes are identified as predisposing to asthma and atopy, but their exact role in contributing to the disease is yet to be determined (3).

Recent studies indicate that airway inflammation and remodelling (or restructuring) are present in patients who do not have asthma, although they are more common in subgroups of patients considered to be at risk for developing symptomatic asthma, such as atopic subjects with asymptomatic AHR (4). When atopic individuals become symptomatic, the observation that airway inflammation and remodelling increase (5) suggests that mechanisms leading to asthma may begin months or years before the onset of symptoms. However, the relative contribution of different components in the inflammatory-remodelling process to the development of AHR and asthma symptoms is still not 
TABLE 2

Overall management of asthma

\begin{tabular}{|c|c|}
\hline Suspect asthma & Make differential diagnosis \\
\hline $\begin{array}{l}\text { Confirm the diagnosis and } \\
\text { assess initial severity }\end{array}$ & $\begin{array}{l}\text { Evaluate symptoms and } \\
\text { measure pulmonary function } \\
\text { tests (spirometry or peak } \\
\text { expiratory flows) }\end{array}$ \\
\hline $\begin{array}{l}\text { Determine possible triggers } \\
\text { and inducers of asthma }\end{array}$ & $\begin{array}{l}\text { Perform a questionnaire, allergy } \\
\text { tests or other tests (to assess } \\
\text { environment, workplace, etc) }\end{array}$ \\
\hline Initiate treatment & $\begin{array}{l}\text { Prescribe the medication required } \\
\text { to achieve asthma control } \\
\text { (see Table } 1 \text { and Figure 1) } \\
\text { Treat associated conditions } \\
\text { (eg, rhinitis) }\end{array}$ \\
\hline Initiate education & $\begin{array}{l}\text { Provide basic elements and, } \\
\text { if possible, refer patient to an } \\
\text { asthma educator }\end{array}$ \\
\hline $\begin{array}{l}\text { Determine the best results } \\
\text { achievable }\end{array}$ & $\begin{array}{l}\text { Check asthma control criteria, } \\
\text { including pulmonary function }\end{array}$ \\
\hline $\begin{array}{l}\text { Determine the minimum } \\
\text { medication needed to keep } \\
\text { the asthma controlled }\end{array}$ & $\begin{array}{l}\text { Progressively reduce the } \\
\text { medication while checking } \\
\text { asthma control }\end{array}$ \\
\hline $\begin{array}{l}\text { Devise an action plan for the } \\
\text { management of exacerbations }\end{array}$ & $\begin{array}{l}\text { Provide a written document or ask } \\
\text { an asthma educator to do so }\end{array}$ \\
\hline Ensure regular follow-up & $\begin{array}{l}\text { Regularly check control criteria } \\
\text { and pulmonary function }\end{array}$ \\
\hline
\end{tabular}

known (6). In the future, it may be possible to prevent asthma by suggesting specific interventions for individuals at high risk for developing asthma, but more work has to be done to determine who will benefit the most from these interventions.

\section{General management of asthma}

As stated in the 1999 document, "the main thrust of asthma therapy is to limit exposure to triggering factors and to reduce the inflammatory process using anti-inflammatory agents" (1). Failure to control the disease through environmental modification or preventive strategies requires a balanced pharmacological approach. This requires individual assessment of the need for therapeutic intervention, and establishment of the risks and the benefits of various therapeutic choices. Treatment plans should be considered therapeutic trials, with careful assessment of their impact on symptoms, lung function, complications related to treatment and overall quality of life. The Asthma Treatment Continuum (7) adopted at the previous Canadian Asthma Consensus Conference appears to be well accepted as a framework by Canadian health care providers (Table 1 and Figure 1). The diagnostic and therapeutic approaches to asthma are summarized in Table 2.

\section{Definition of asthma control and severity}

No simple scoring system is available to quantify disease control accurately. The criteria defined in Table 3 provide an overall evaluation of 'acceptable' control; attempts to define disease control with symptom scores have been published but are used mostly in research (8). A recent Canadian survey showed that many asthma patients have poor control of their disease, resulting in reduced quality of life and significant in-
TABLE 3

Asthma control criteria

Daytime symptoms less than four days/week

Night-time symptoms less than one night/week

Normal physical activity

Mild, infrequent exacerbations

No absenteeism due to asthma

Fewer than four doses/week of short acting beta2-agonist needed ${ }^{\star}$ FEV ${ }_{1}$ or PEF $90 \%$ of personal best or greater

Diurnal variability in PEF less than $10 \%$ to $15 \%$

${ }^{*}$ Apart from one dose/day before exercise. FEV 1 Forced expiratory volume in $1 \mathrm{~s}$; PEF Peak expiratory flow

TABLE 4

Some care gaps identified in asthma management

Insufficient patient education, particularly on what asthma is and how to control it

Insufficient use of objective measurements of airflow obstruction (peak expiratory flow, forced expiratory volume in $1 \mathrm{~s}$ )

Misunderstanding regarding the role and side effects of medications Overuse of beta2-agonists and insufficient use of anti-inflammatory agents

Lack of continuity of care

\section{TABLE 5}

Asthma medications

'Relievers' (for intermittent symptoms)
Short/fast-acting beta2-agonists
Ipratropium (rarely)
'Controllers' (maintenance therapy)
Anti-inflammatory medications
Inhaled and/or oral glucocorticosteroids
Leukotriene receptor antagonists
Antiallergic agents (cromoglycate, nedocromil)
Bronchodilators
Long acting, inhaled beta2-agonists (salmeterol, formoterol)
Theophylline (rarely)

terference with daily activities (9). Some of the factors that contribute to poor asthma control are listed in Table 4. Improved asthma control may be achieved through appropriate environmental measures, patient education and individual pharmacotherapy - all should be assessed regularly and treatment adjusted accordingly.

The assessment of severity has usually been based on the frequency and duration of respiratory symptoms, and the degree of airflow limitation. However, once asthma is well controlled, one of the best ways to judge severity is to determine the level of treatment needed to maintain acceptable control, and to evaluate the presence of severe asthma events, urgent care needs and overall influence of asthma on daily activities (see section on Diagnosis) (1).

\section{Medications}

There are several new molecules under investigation that affect different immune and mediator mechanisms. These 
TABLE 6

Messages regarding medication

Asthma medications should be used at the lowest dose and frequency required to maintain acceptable asthma control

Medication should not be used as a substitute for proper control of the environment

Asthma medications are considered to be safe over many years when used appropriately

Long term use of anti-inflammatory agents has not resulted in any clinically significant reduction in their efficacy

Medication should be adapted to the needs of each asthma patient

Patients should learn how to modify their treatment rapidly when asthma flares

agents will potentially be useful in the prevention or treatment of asthma. In addition to new therapies still under investigation, it has been suggested that the indications for use of currently approved medications may require some modification. For example, because formoterol has been shown to have both rapid onset and long acting bronchodilator properties, its role in therapy may need to be reconsidered (see section on beta2-agonists).

Asthma medications can still be divided into two main categories: controllers and relievers (Table 5). Relievers are best represented by the short acting beta2-agonists, and controllers or preventers by inhaled glucocorticosteroids. When small to moderate doses of inhaled glucocorticosteroids are insufficient to control asthma symptoms, additional therapy, such as the long acting, inhaled beta2-agonists salmeterol and formoterol, or the leukotriene antagonists zafirlukast and montelukast, may be added as adjuncts. When explaining treatment to patients with asthma, it is essential to be very specific about the role that each medication plays in disease compared with in symptom control (Table 6).

New propellants such as hydrofluoroalkane (HFA) propellants, combined agents such as the fluticasone/salmeterol inhalers, and new devices have become available. An update on asthma pharmacology is provided in the next sections of this document.

\section{Nonpharmacological treatment}

Asthma education and environmental control are considered essential in the treatment of asthma. Progress has been made in improving the standards for educational interventions and in making them more available in Canada. A national asthma educators' certification program has been made available through the Canadian Network for Asthma Care (http://www.cnac.net/), and is linked to regional and provincial programs. There is still a need to improve awareness and acceptance of the role of asthma education in the continuum of care. Support is necessary from primary care physicians to ensure appropriate referrral and participation in long term care. Provincial and regional health authorities need to establish stable funding for these programs.

\section{Treatment of associated conditions}

There is a need to suspect, diagnose and treat associated conditions, such as rhinitis and/or sinusitis or gastroesophageal reflux, that may affect asthma control (10).

\section{Conclusion}

In most instances, asthma can be well controlled and the consequences of the disease minimized. The following sections will update our knowledge on recent developments in this field.

\section{REFERENCES}

1. Boulet LP, Becker A, Bérubé D, Beveridge R, Ernst P, on behalf of the Canadian Asthma Consensus Group. Canadian Asthma Consensus Report, 1999. CMAJ 1999;161(11 Suppl):S1-61.

2. Harris WR. Guidelines for writing guidelines. CMAJ 1994;151:507-8.

3. Cookson WO, Moffatt MF. Genetics of asthma and allergic disease. Hum Mol Genet 2000;9:2359-64.

4. Boulet LP, Chakir J, Dubé J, Laprise C, Boutet M, Laviolette M. Airway inflammation and structural changes in airway hyperresponsiveness and asthma: An overview. Can Respir J 1998;5:16-21.

5. Laprise C, Laviolette M, Boutet M, Boulet LP. Asymptomatic airway hyperresponsiveness: Relationships with airway inflammation and remodelling. Eur Respir J 1999;14:63-73.

6. Holgate ST. The epidemic of allergy and asthma. Nature 1999;402(6760 Suppl):B2-4.

7. Ernst P, FitzGerald JM, Spier S. Canadian Asthma Consensus Conference: Summary of recommendations. Can Respir J 1996;3:101-14.

8. Asthma in Canada: A Landmark Survey. (http://www.asthmaincanada.com) (Version current at February 19, 2001)

9. Juniper EF, O'Byrne PM, Ferrie PJ, King DR, Roberts JN. Measuring asthma control. Clinic questionnaire or daily diary? Am J Respir Crit Care Med 2000;162:1330-4.

10. Rachelefsky GS, Katz RM, Siegel SC. Chronic sinus disease with associated reactive airway disease in children. Pediatrics 1984;73:526-9.

\section{DIAGNOSIS AND EVALUATION OF ASTHMA} Denis Bérubé, Donald W Cockcroft

Recommendations regarding the diagnosis and evaluation of asthma in adults have not changed since the publication of the 1999 guidelines (1). Diagnosis, assessment of pretreatment severity and control should still be based on the objective assessment of variable airway obstruction and symptoms (including as-needed rescue medication needs and morbidity). Post-treatment severity in the well controlled patient should be based on the minimum medication need. When optimal control cannot be achieved, persisting airflow obstruction, symptoms and morbidity are also included in the definition of severity. Although not routinely available, examination of induced sputum shows promise in the evaluation of asthma control and as a guide to treatment $(2,3)$.

In 1998, the Canadian Asthma Consensus Group stated that for children able to perform reproducible spirometry, the diagnosis of asthma and the evaluation of its severity could be established by the same method as that used for adults (1); this still applies in the year 2001. The following discussion deals with patients who are unable to perform spirometry.

\section{Variable airway obstruction}

A major problem facing pediatricians who treat asthma is the inability to routinely obtain noninvasive and reliable assessments of variable airway obstruction in patients unable to produce reproducible spirometry (ie, in children younger 
than five or six years of age). Over recent years, forced oscillation has been used successfully to measure total respiratory resistance in children aged three years and older who cannot perform spirometry $(4,5)$. However, the difficulties persist in assessing airway obstruction and its reversibility in younger children. Many methods of obtaining airway function measurements have been described in young children, including whole body plethysmography, forced expiratory flow following rapid thoracoabdominal compression, single- or multiple-breath occlusion techniques, forced oscillation or forced deflation techniques, and measurements made during tidal breathing. While standards and normal values have been published (6), most methods are invasive to a certain extent, require sedation, necessitate specialized equipment and personnel, and are not widely available. Their inter- and intra-individual variability often preclude their use in the assessment of airway obstruction reversibility after bronchodilator administration in all but the patients with the most severe disease $(7,8)$. Furthermore, responsiveness to bronchoconstrictors after inhalation challenge, which may be used reliably in older children and adults, has never been shown to differentiate between normal infants and recurrent wheezers. These issues led some authors to question whether airway hyper-reactivity was a feature of normal early childhood, disappearing in most individuals except those destined to suffer from asthma. Others argue that hyper-reactive airways may be artificially created by the measurement techniques used for assessment or the inability to standardize the amount of bronchoconstrictor inhaled by young infants compared with older children (7-13). Overall, assessment of airway function in subjects unable to perform spirometry or forced oscillation has not yet gained popularity within the pediatric community due to its inability to provide reliable and management-modifying data easily.

\section{Airway inflammation}

Although the assessment of the presence and severity of airway inflammation is still not part of the routine clinical management of patients with asthma, it is more and more easily and reliably obtained through the analysis of induced sputum. This method has been described and used in pediatrics $(14,15)$, but has not yet reached acceptance and recognized usefulness in adult medicine, although more studies on the role of this method in the current management of asthma in adults are needed. Again, this method cannot yet be used in uncooperative patients, and airway inflammation still cannot be assessed noninvasively in young patients.

\section{Symptoms}

As in 1998, for uncooperative children unable to perform reproducible spirometry, careful and repeated history-taking and physical examination are still the best, if not the only, diagnostic tools for most clinicians. Wheezing and cough in early childhood commonly describe a heterogeneous group of patients. In fact, the younger the child is at the onset of symptoms, the more likely that a diagnosis other than asthma should be considered and excluded. Previous International
Consensus Statements on Asthma have even recommended that asthma in children be considered a diagnosis of exclusion (16). Large epidemiological data show that virus-induced wheezing in infancy affects up to one-third of otherwise normal children, of which two-thirds do not have the usual risk factors associated with asthma. The hypothesis is that these infants have narrower intrathoracic airways that predispose them to early wheezing when their airways are affected by virus-induced inflammation. These 'early wheezers' have a favourable prognosis, with a disappearance of wheezing after their third birthday. The remaining one-third carry a less favourable prognosis, with an increased likelihood of long term, recurrent airway obstruction usually associated with atopy - the classical asthma risk factor $(17,18)$.

In 1998, the Canadian Asthma Consensus Group thought that the likelihood of asthma increased when certain risk factors and clinical patterns were present. Included among the risk factors were severe episodes of wheezing; wheezing after one year of age; more than three episodes of wheezing in a given year; a personal history of atopy; a family history of asthma or atopy; maternal cigarette smoking; clinical benefits from acute bronchodilator therapy; clinical evidence of improvement after anti-inflammatory treatment; chronic cough (especially nocturnal or associated with exercise); and wheezing in patients who are unlikely to have a viral infection. As awkward as it may be, this pragmatic approach is still a clinically helpful tool to identify preschoolers either who have asthma or in whom treatment trials with asthma therapy are appropriate.

\section{REFERENCES}

1. Boulet LP, Becker A, Bérubé D, Beveridge R, Ernst P, on behalf of the Canadian Asthma Consensus Group. Canadian Asthma Consensus Report, 1999. CMAJ 1999;161(11 Suppl):S1-61.

2. Pizzichini MM, Pizzichini E, Clelland L, et al. Prednisone-dependent asthma: inflammatory indices in induced sputum. Eur Respir J 1999;13:15-21.

3. Hargreave FE, Leigh R. Induced sputum, eosinophilic bronchitis, and chronic obstructive pulmonary disease. Am J Respir Crit Care Med 1999;160:S53-7.

4. Ducharme FM, Davis GM, Ducharme GR. Pediatric reference values for respiratory resistance measured by forced oscillation. Chest 1998:113:1322-8.

5. Lebecque P, Spier S, Lapierre JG, Lamarre A, Zinman R, Coates AL. Histamine challenge test in children using forced oscillation to measure total respiratory resistance. Chest 1987;92:313-8.

6. Stocks J, Sly PD, Tepper RS, Morgan WJ, eds. Infant Respiratory Function Testing. New York: Wiley-Liss, 1996.

7. Prendiville A, Green S, Silverman M. Bronchial responsiveness to histamine in wheezy infants. Thorax 1987;42:92-9.

8. Delacourt C, Benoist MR, Waernessyckle S, et al. Repeatability of lung function tests during methacholine challenge in wheezy infants. Thorax 1998;53:933-8.

9. LeSouëf PN, Geelhoed GC, Turner DJ, Morgan SE, Landau LI. Response of normal infants to inhaled methacholine. Am Rev Respir Dis 1989;139:62-6.

10. Clarke JR, Reese A, Silverman M. Bronchial responsiveness and lung function in infants with lower respiratory tract illness over the first six months of life. Arch Dis Child 1992;67:1454-8.

11. Tepper RS. Airway reactivity in infants: a positive response to methacholine and metaproterenol. J Appl Physiol 1987;62:1155-9.

12. Montgomery GL, Tepper RS. Changes in airway reactivity with age in normal infants and young children. Am Rev Respir Dis 1990; 142:1372-6.

13. Turner DJ, Landau LI, LeSouëf PN. The effect of age on bronchodilator responsiveness. Pediatr Pulmonol 1993;15:98-104. 
14. Grootendorst DC, van den Bos JW, Romeijn JJ, et al. Induced sputum in adolescents with severe stable asthma. Safety and the relationship of cell counts and eosinophils cationic protein to clinical severity. Eur Respir J 1999;13:647-53.

15. Twaddell SH, Gibson PG, Carty K, Woolley KL, Henry RL. Assessment of airway inflammation in children with acute asthma using induced sputum. Eur Respir J 1996;9:2104-8.

16. Warner JO, Naspitz CK, for the International Pediatric Asthma Consensus Group. Third International Pediatric Consensus statement on the management of childhood asthma. Pediatr Pulmonol 1998;25:1-17.

17. Martinez FD, Wright AL, Taussig LM, Holberg CJ, Halonen M, Morgan WJ, for the Group Health Medical Associates. Asthma and wheezing in the first six years of life. N Engl J Med 1995;332:133-8.

18. Martinez FD. Definition of pediatric asthma and associated risk factors. Pediatr Pulmonol Suppl 1997;15:9-12.

\section{ENVIRONMENTAL CONTROL}

\section{Allan B Becker}

The Canadian Asthma Consensus Report, 1999 (1) clearly documented the relation between sensitization to environmental allergens and asthma in both children and adults. However, there is debate as to the value of environmental control measures in the management of asthma, which is best illustrated in the case of house dust mite allergy. A meta-analysis (2) was unable to find a positive effect of house dust mite environmental control in patients with asthma. The authors noted that "current chemical and physical methods aimed at reducing exposure to allergens from house dust mites seemed to be ineffective" (2). In that analysis, only five of 23 studies reviewed showed a significant fall in the concentration of house dust mite allergen, but four of the five studies were associated with some measured improvement of asthma. A number of studies of the relation between house dust mite allergen and asthma that were not considered in the metaanalysis showed the importance of house dust mite avoidance measures in the control of asthma (3-6). For example, Murray and Ferguson (3) showed that a sterile bedroom environment was associated with marked improvement in children with asthma due to house dust mite allergy. In an open study of adults with asthma, Platts-Mills et al (4) showed that airway responsiveness improved over a period of months in an allergen-free hospital environment. As well, residence at high altitude, where mite allergens are low, has been used successfully in the treatment of asthma in patients allergic to house dust mite (5).

One recent review (7) concluded that environmental control of allergens should be an integral part of the management of sensitized patients. The authors reviewed 31 studies, including some of those used in the meta-analysis noted above (2). In a number of the studies, there was some evidence of clinical benefit, although the outcome parameter considered in each of the studies was somewhat different. The authors of the review stated that "There remains an urgent need to develop a large scale trial of the widespread applicability of mite allergen avoidance and the effect on patient symptoms, exacerbation rate, use of medication and overall health costs" (7). What appears critical - and rather logical - in each of the positive studies is the need to decrease significantly the concentration of house dust mite allergen to have an impact on the underlying asthma pathophysiology in patients allergic to house dust mites. For example, a recent study (8) found that comprehensive environmental control, which included mattress covers and active high efficiency particulate air (HEPA) cleaners, was required to decrease levels of house dust mite and cat allergens effectively. Associated with this was a statistically significant improvement in airway responsiveness. Similarly, another double-blind, randomized trial compared asthma progression over one year in children whose homes received a standard environmental control intervention with children whose homes received aggressive intervention for dust mite elimination (9); dust mite levels were lowered and bronchial hyper-responsiveness improved.

Several specific observations are worth noting. First, sleeping in bunk beds constitutes a greater risk for developing asthma for subjects sleeping in the bottom bed (10). Bunk beds should be discouraged in families with an atopic background and sensitized children. Also of interest is the observation that synthetic pillows accumulate house dust mite allergen more rapidly than feather pillows $(11,12)$. It has been observed that the house dust mite avoidance measure of encasing the mattress with a vapour-impermeable cover and hot washing bed linen reduced not only mite aeroallergen but also cat allergen $(13,14)$. There are new data on reducing dog allergen levels by washing the dog, but the authors reported that the dog needs to be washed at least twice a week to maintain the reduction in recoverable dog allergen (15). The use of a dryer can kill all house dust mites if a temperature greater than $55^{\circ} \mathrm{C}$ is maintained for 10 to $15 \mathrm{~min}$. That is, the thermal death point and time required to kill mites is about the same in air as it is in water.

\section{Pollutants and/or adjuvants}

Environmental tobacco smoke (ETS) is a risk factor for the development of childhood asthma, and is frequently responsible for the worsening of asthma symptoms in children and adults (16). The earlier, longer and greater the degree of ETS exposure in early childhood, the greater the likelihood of asthma developing in children $(17,18)$. ETS is by far the single most important pollution exposure factor associated with asthma in infants and children, and must be avoided.

\section{Environmental control: What is effective and what is practical?}

Avoidance of the principal indoor aeroallergens, including house dust mites, companion animal(s) (particularly cats) and cockroaches, appears to have the greatest potential for benefit given their strong relationship to asthma. The removal of pets from the home is the most effective way to reduce exposure to cats or dogs (19). However, after removal of a cat, it can take more than six months for cat allergen levels to return to baseline. Unfortunately, removal of a pet from the home is loaded with psychosocial issues, and many - perhaps most - families will not agree to the removal of the animal to which an individual with asthma is sensitized. As a result of the difficulty of pet removal from the home, a number of alternatives have been considered to allow the animal to remain 'in situ'. Although there is a marked reduction in 
TABLE 1

\section{Environmental therapy for house dust mites}

Maintain relative humidity below $50 \%$

Encase mattresses, boxsprings (and possibly pillows) in mite- and

mite allergen-impermeable covers

Launder bed linen in hot $\left(55^{\circ} \mathrm{C}\right)$ water

Remove carpeting, where possible

Air filters do not affect reservoir levels of house dust mite allergen

\section{TABLE 2}

\section{Environmental therapy for pet allergens}

Removal of the pet from the home is the most effective approach

Where removal is not possible, the following may decrease airborne pet allergen:

Pet exclusion from the bedroom

Use of a high efficiency particulate air (HEPA) room cleaner

Mattress and pillow encasement with mite-impermeable covers

Removal of carpeting

Frequent vacuuming of upholstered furniture with a HEPA

filtered vacuum

Washing the pet twice weekly (this must NOT be done by the allergic individual)

airborne cat allergen (Fel d 1) after washing a cat on a weekly basis (20), subsequent studies have shown that washing effects a transient decrease in airborne cat allergen levels (21), and the animal probably needs to be washed twice a week to decrease respirable allergen over time (14).

Cat allergen exposure also occurs in public environments such as schools, hospitals and other public buildings; it is presumed that pet allergen is transported to these sites on clothing, and settles into reservoirs such as upholstered furniture and carpeting. Children from homes with cats carry significant amounts of cat allergen on their clothing (22), and, to a great extent, the cat has become a source of communitybased allergen. The authors suggested that "carpeting should be discouraged in environments such as schools and childcare centres where children spend considerable time" (22). Carpeting appears to be an important risk factor for allergy and asthma. Similarly, upholstered chairs in hospitals, and presumably other public places, constitute a significant reservoir of cat and dog allergen (23). Frequent vacuuming (three times/week using an HEPA filter vacuum cleaner) has been shown to significantly reduce allergen levels in upholstered furniture (23).

Unfortunately, compliance with allergen avoidance recommendations is very poor, even with the most simple recommendations, such as encasement of mattresses (24). We propose that allergen avoidance is a critically important goal for allergic patients in any asthma management program. While removal of a sensitized individual to an allergen-free environment, such as a hospital or a mountain retreat, can result in dramatic improvement clinically and in terms of airway function, this is neither practical nor possible in most instances. Environmental control is generally given lip service in asthma therapy. As the potential value for environ-
TABLE 3

\section{Key messages about allergen exposure}

Increased allergen exposure increases risk for allergy and asthma

Allergic patients exposed to high concentrations of allergen to

which they are sensitized have a greater risk for acute, severe

asthma

Intervention must significantly decrease allergen exposure to affect the underlying asthma

Carpeting is a risk factor for allergy and asthma

Removal of a pet from the home is the most effective means to reduce exposure to a cat or dog

Encasement of a mattress is the single most effective method to reduce exposure to house dust mite allergen

${ }^{*}$ All recommendations are level I

mental therapy increases, we must give serious consideration to proper and effective means for environmental control (Tables 1 and 2). Compliance should not be a problem with house dust mite avoidance measures, but compliance will continue to be a major issue in relation to pets. Given the psychosocial issues and the widespread exposure to cat allergen, issues of ventilation and filtration in the home and in the work environment will be of increasing importance. Proper and effective methods of ventilation and filtration at home and at work must be the focus of increased research, particularly given the epidemic of allergy and asthma in the industrialized world over the past quarter of a century. We now have at our disposal effective means to assess rigorously the impact of environmental control on patients with asthma. Improved understanding of environmental control is critical to our approach to this major health problem. Key messages are found in Table 3.

\section{REFERENCES}

1. Boulet LP, Becker AB, Bérubé D, Beveridge R, Ernst P, on behalf of the Canadian Asthma Consensus Group. Canadian Asthma Consensus Report, 1999. CMAJ 1999;161(11 Suppl):S1-61.

2. Gotzsche PC, Hammarquist C, Burr M. House dust mite control measures in the management of asthma: meta-analysis. BMJ 1998;317:1105-10.

3. Murray AB, Ferguson AC. Dust-free bedrooms in the treatment of asthmatic children with house dust or house dust mite allergy: a controlled trial. Pediatrics 1983;71:418-22.

4. Platts-Mills TA, Tovey ER, Mitchell EB, Moszoro H, Nock P, Wilkins SR. Reduction of bronchial hyperreactivity during prolonged allergen avoidance. Lancet 1982;2:675-8.

5. Boner AL, Nicro E, Antolini L, Vallotta AE, Gaburro D. Pulmonary function and bronchial hyperreactivity in asthmatic children with house dust mite allergy during prolonged stay in the Italian Alps (Misurina, 1756 m). Ann Allergy 1985;54:42-5.

6. Ehnert B, Lau-Schadendorf S, Weber A, Buettner P, Schou C, Wahn U. Reducing domestic exposure to dust mite allergen reduces bronchial hyperreactivity in sensitive children with asthma. J Allergy Clin Immunol 1992;90:135-8.

7. Custovic A, Simpson A, Chapman MD, Woodcock A. Allergen avoidance in the treatment of asthma and atopic disorders. Thorax 1998;53:63-72.

8. van der Heide S, Kauffman HF, Dubois AEJ, de Monchy JGR. Allergen reduction measures in houses of allergic asthmatic patients: effects of air-cleaners and allergen-impermeable mattress covers. Eur Respir J 1997;10:1217-23.

9. Shapiro GG, Wighton TG, Chinn T, et al. House dust mite avoidance for children with asthma in homes of low-income families. J Allergy Clin Immunol 1999;103:1069-74.

10. Gaig P, Enrique E, Garcia-Ortega P, Olona M, del Mar San Miguel M, Richart C. Asthma, mite sensitization, and sleeping in bunks. Ann Allergy Asthma Immunol 1999;82:531-3. 
11. Frosh AC, Sandhu G, Joyce R, Strachan DP. Prevalence of rhinitis, pillow type and past and present ownership of furred pets. Clin Exp Allergy 1999;29:457-60.

12. Rains N, Siebers R, Crane J, Fitzharris P. House dust mite allergen (Der p 1) accumulation on new synthetic and feather pillows. Clin Exp Allergy 1999;29:182-5.

13. Quirce S, Dimich-Ward H, Chan H, et al. Major cat allergen (Fel d I) levels in the homes of patients with asthma and their relationship to sensitization to cat dander. Ann Allergy Asthma Immunol 1995;75:325-30.

14. Carswell F, Oliver J, Weeks J. Do mite avoidance measures affect mite and cat airborne allergens? Clin Exp Allergy 1999;29:193-200.

15. Hodson T, Custovic A, Simpson A, Chapman M, Woodcock A, Green R. Washing the dog reduces dog allergen levels, but the dog needs to be washed twice a week. J Allergy Clin Immunol 1999;103:581-5.

16. Weiss ST, Tager IB, Schenker M, Speizer FE. The health effects of involuntary smoking. Am Rev Respir Dis 1983;128:933-42.

17. Ehrlich RI, Du Toit D, Jordaan E, et al. Risk factors for childhood asthma and wheezing: importance of maternal and household smoking. Am J Respir Crit Care Med 1996;154:681-8.

18. Health effects of outdoor air pollution. Committee of the Environmental and Occupational Health Assembly of the American Thoracic Society. Am J Respir Crit Care Med 1996;153:3-50.

19. Wood RA, Chapman MD, Adkinson NF, Eggleston PA. The effect of cat removal on allergen content in household-dust samples. J Allergy Clin Immunol 1989;83:730-4.

20. de Blay F, Chapman MD, Platts-Mills TAE. Airborne cat allergen (Fel d 1): environmental control with the cat in situ. Am Rev Respir Dis $1991 ; 143: 1334-9$

21. Avner DB, Perzanowski MS, Platts-Mills TAE, Woodfolk JA. Evaluation of different techniques for washing cats: quantitation of allergen removed from the cat and the effect on airborne Fel d 1 . J Allergy Clin Immunol 1997;100:307-12.

22. Patchett K, Lewis S, Crane J, Fitzharris P. Cat allergen (Fel d 1) levels on school children's clothing and in primary school classrooms in Wellington, New Zealand. J Allergy Clin Immunol 1997;100:755-9.

23. Custovic A, Fletcher A, Pickering CAC, et al. Domestic allergens in public places III: house dust mite, cat, dog and cockroach allergens in British hospitals. Clin Exp Allergy 1998;28:53-9.

24. Korsgaard J. Preventive measure in house-dust allergy. Am Rev Respir Dis 1982;125:80-4.

\section{PATIENT EDUCATION}

\section{Johanne Côté, Tom Kovesi}

Research published since 1998 in relation to asthma education interventions has increased support for the guideline recommendations (Table 1). Elements to consider when designing education programs are summarized in Table 2.

\section{Content of the asthma education program}

A recent meta-analysis (1) confirmed that asthma education programs aimed only at improving knowledge about asthma do not improve asthma morbidity. Another metaanalysis (2) assessed the value of asthma education programs based on self-monitoring of asthma symptoms or peak expiratory flow (PEF) with step up or down of asthma therapy according to a written self-action plan with the routine community asthma care. The findings from 24 clinical trials showed that programs using self-management based on a written action plan can significantly decrease the number of hospitalizations, emergency room visits, unscheduled visits to the doctor, days off from work or school, and nocturnal asthma symptoms.

Asthma education programs showing improved outcomes have used different methods, making it difficult to identify the key components of the intervention that were responsible for the observed results. This issue has again been emphasized in a review of all educational studies published between 1979 and 1998 (3). A recent clinical trial (4) involving
TABLE 1

Conclusions and recommendations on asthma education and monitoring

Education is an essential component of asthma therapy and should be offered to patients (both adults and children) at the time of emergency department visit and/or hospitalization (level I)

All patients should have written self-action plans for self-management that include medication adjustment in response to severity, frequency of symptoms and medication requirements for relief of symptoms (level I)

Patient self-monitoring may be effective using either measurement of PEF or monitoring of asthma symptoms (level I)

Monitoring PEF may be useful in some patients, particularly those who are poor perceivers of airflow obstruction (level III)

Monitoring of pulmonary function in physicians' offices should be routine (level III)

Patients with severe or poorly controlled asthma should be referred to an asthma expert (level II)

PEF Peak expiratory flow

TABLE 2

Key elements to remember before designing an asthma education program

The goal of asthma education is control of asthma via improved knowledge and change in behaviour (level III)

Asthma education should not rely on written or videotape material alone (level I)

Asthma education is effective only in the presence of effective asthma therapy (level III)

Education must be provided at each patient contact (level II)

Good communication between health professionals and coordination of their interventions is essential (level III)

patients enrolled at the time of an exacerbation concluded that a written self-action plan, combined with teaching of inhaler technique and a structured educational intervention, can significantly decrease the number of unscheduled visits for asthma in comparison with usual care or a short educational intervention that included only the prescription of the written self-action plan and teaching of the inhaler technique.

\section{Impact of asthma education on health care use}

A meta-analysis found that asthma education may decrease the number of emergency department visits and hospitalizations in adults with asthma (2). The studies reporting benefits have targeted specific subgroups of patients, such as those visiting emergency departments or hospitalized for asthma exacerbations. A study done in the United Kingdom (5) showed a significant decrease in the number of hospitalizations, emergency department visits, antibiotic use and consultations to general practitioners in a group of patients with asthma from a low socioeconomic area after an asthma education intervention. Because only one-third of the patients had previously been admitted to or visited the emergency department for asthma, it seems that benefits may not be restricted to high risk patients (5). The decrease in health care use was not observed in non-White patients with asthma living in the same 
region; this finding was not related to language barriers. A study done in Brazil (6) reported a decrease in asthma morbidity and an improvement in asthma knowledge, symptoms and quality of life, even in poorly educated people (with less than five years of education). Significant decreases in emergency department visits and hospitalizations were also observed in a group of inner-city patients in the United States who received asthma education during hospitalization (7). These results suggest that asthma education can decrease asthma morbidity in subgroups with lower levels of education or lower socioeconomic status. A nonrandomized trial involving a nurse to adjust medications in collaboration with the primary care physicians was reported to improve pulmonary function and markers of pulmonary inflammation, to reduce emergency department visits, and to reduce absenteeism from work and school (8). Despite many studies reporting benefits from education, it has been suggested that in the presence of expert asthma care and the provision of good basic asthma education, the addition of a more intensive asthma education program may have limited clinical and cost benefits (9).

\section{Cost effectiveness}

In a study comparing educational interventions based on a written self-action plan and peak flow monitoring in one session at the beginning versus reinforcement every three months for a year, no significant difference in clinical outcome was observed, but the intervention with reinforcement was considered less cost effective (10).

\section{Asthma education in children}

Asthma education can also decrease asthma morbidity in the pediatric population. Children referred to a nurse practitioner-based asthma education program, in which the educator had access to an asthma expert for consultation, had reductions in the number of emergency department visits and admissions compared with control subjects randomly assigned to a single education session. An economic analysis determined that more than US $\$ 11.00$ was saved for each dollar spent on the educator (11). Another study using a similar program to provide a structured, $20 \mathrm{~min}$ session to inpatients focusing on guided self-management and a written action plan reported marked reductions in readmissions, emergency department visits and unscheduled physician visits (12). In a study of children frequently admitted to hospital for asthma exacerbations, a significant decrease in health care use was reported in the intervention group (14). Asthma health care costs decreased by $\$ 721 /$ child/year in the intervention group and by $\$ 178 /$ child/year in the control group (14). However, in a pre- and postintervention study, a oneweek asthma camp for underprivileged children with severe asthma resulted in marked reductions in hospitalizations and emergency department visits, and reduced absenteeism from school over the following year. The program saved over US\$2000 in direct health costs for each camper (15).

It was disappointing to note that an extensive intervention program for inner-city American children reported only modest improvements in asthma symptom-free days. This may serve to emphasize previous evidence that education is most effective when accompanied by effective medical therapy (13).

Education and environmental control: A trial that involved briefly informing parents of children with asthma of the harmful effects of passive smoke exposure was ineffective at reducing the children's exposure to cigarette smoke, and was no more effective than simply providing them with a brochure; one-year smoking cessation rates were less than $3 \%$ in both groups (16). Further research is needed in this field to find better ways of influencing parents' behaviour.

Educational methods: The use of a touch-screen computer program alone resulted in a trend toward improved asthma knowledge one month later, although the effects on behaviour or outcome were not assessed (17).

Monitoring: As shown in the next section, research published since early 1999 supports the last Canadian Guidelines recommendations.

Home monitoring: A recent randomized trial (18) showed that both symptoms and PEF-based self-management plans, in conjunction with asthma education, were similarly effective at improving outcome measures including pulmonary function, airway responsiveness, symptoms and quality of life. However, therapy was altered as specified by either action plan in only $30 \%$ of the exacerbations in either group. Another Canadian study (19) using a PEF meter with electronic memory found that compliance with PEF monitoring was generally poor and fell steadily over time, with only $63 \%$ compliance at one month and 33\% at 12 months. Fabricated entries in the paper diary were quite common, and compliance could not be predicted by education, income level or asthma severity.

When results at one year before intervention were compared with those one year after, asthma morbidity decreased equally in subjects using either an action plan based on symptoms or on peak flow monitoring (20). In the study by Côté et al (4), asthma morbidity decreased significantly even if most of the participating patients with asthma had a self-action plan based on asthma symptoms. This suggests that for most patients, action plans based on symptoms may be adequate, except in poor perceivers or those particularly motivated to monitor PEF (19). There is still little evidence that PEF monitoring is more useful in patients with severe asthma (21). PEF monitoring and diary recording of a visual analogue score for breathlessness were shown to identify better those patients with poor symptom perception and those with exaggerated symptom responses to airway narrowing (22).

In regard to the limitations of PEF measurements, a recent large study (23) of children with asthma, 30\% of pulmonary function tests where PEF was normal, forced expiratory volume in $1 \mathrm{~s}\left(\mathrm{FEV}_{1}\right)$ or $\mathrm{FEF}_{25-75}$ was abnormal, and, in some cases, was severely reduced, emphasizing the low sensitivity of PEF for the detection of airflow limitation. Furthermore, a 'spitting manoeuvre' into a peak flow meter could falsely increase PEF (24). A recent review (21) of commercially available PEF meters reported considerable variation in accuracy, although reproducibility was good in all devices described. 
A study (25) found wide variations in PEF readings in the same patients using different devices, suggesting that PEF should be checked in the office with the patient's own device or at least with the same type of PEF meter.

Electronic home monitoring has been further refined. Several devices provide reasonably accurate measurement of pulmonary function (PEF and $\left.\mathrm{FEV}_{1}\right)$ and allow recording of diary information such as beta2-agonist use. Because the devices provide the time and date, compliance with monitoring can be assessed (26). A study on home spirometry with Internet-based links to health care providers found that $\mathrm{FEV}_{1}$ measurements correlated closely with values obtained in a pulmonary function laboratory, and that the system could be used even in a population that had minimal experience with computers (27).

However, home spirometry can sometimes be inaccurate for reasons not encountered in a hospital laboratory, such as taking measurements in windy places or near a fan (28). The Chronolog (Forefront Technologies Inc, USA), which electronically records the date and time that a metered dose inhaler (MDI) is actuated, has been found to be useful in identifying nonadherence and helping health care professionals to develop a strategy to improve treatment plan adherence (29).

Physician monitoring: A recent British survey (30) has suggested the value of using an asthma management stamp in the rapid assessment of asthma control in an office setting. A hand-held office spirometer, which provides detailed prompts to improve the quality of results, was recently assessed in a study of primary care practices in New Zealand (31). Practices were randomly assigned to receive either basic instructions for the device's operation or a $2 \mathrm{~h}$ practical workshop emphasizing acceptability and reproducibility criteria. Test results generally did not meet American Thoracic Society criteria in either group but were significantly more likely to be acceptable in the workshop group. However, even 'unacceptable' results may be adequate to provide clinically useful information. A refresher workshop and training in pulmonary function interpretation were also found to be important (31).

The American National Lung Health Education Program has suggested that inexpensive spirometers be developed for more widespread use in physicians' offices. Such spirometers should report only $\mathrm{FEV}_{1}$ and $\mathrm{FEV}_{6}$ as a surrogate of forced vital capacity (FVC), on the assumption that measuring expiratory flow for $10 \mathrm{~s}$ or longer to determine FVC is more difficult and requires more precise equipment (32). Office spirometers would require on-screen prompts to improve the quality of testing. Manufacturer's recommendations on the frequency of calibration would still need to be followed. Such devices would facilitate more accurate objective measurements of pulmonary function in the office than peak flow meters. However, predicted values for $\mathrm{FEV}_{6}$ are different than for FVC and may be less widely available. Workshops for office personnel performing spirometry may further improve the quality of testing (31).

\section{REFERENCES}

1. Gibson PG, Coughlan J, Wilson AJ, et al. Limited (information only) patient education programs for adults with asthma. Cochrane Database Syst Rev 2000;2:CD001005.
2. Gibson PG, Coughlan J, Wilson AJ, et al. Self-management education and regular practitioner review for adults with asthma. Cochrane Database Syst Rev 2000;2:CD001117.

3. Sudre P, Jacquemet S, Uldry C, Perneger TV. Objectives, methods and content of patient education programmes for adults with asthma: systematic review of studies published between 1979 and 1998 . Thorax 1999;54:681-7.

4. Côté J, Bowie D, Robichaud P, Parent JG, Boulet LP. Evaluation of 2 different interventions for adult patients consulting for an acute exacerbation of asthma. Am J Crit Care Med. (In press)

5. Moudgil H, Marshall T, Honeybourne D. Asthma education and quality of life in the community: a randomised controlled study to evaluate the impact on white European and Indian subcontinent ethnic groups from socioeconomically deprived areas in Birmingham, UK. Thorax 2000;55:177-83.

6. de Oliveira MA, Faresin SM, Bruno VF, de Bittencourt AR, Fernandes ALG. Evaluation of an educational programme for socially deprived asthma patients. Eur Respir J 1999;14:908-14.

7. George MR, O’Dowd LC, Martin I, et al. A comprehensive educational program improves clinical outcome measures in inner-city patients with asthma. Arch Intern Med 1999;159:1710-6.

8. Lindberg M, Ahlner J, Moller M, Ekstrom T. Asthma nurse practice - a resource-effective approach in asthma management. Respir Med 1999;93:584-8.

9. Bailey WC, Kohler CL, Richards JM Jr, et al. Asthma self-management: do patient education programs always have an impact? Arch Intern Med 1999;159:2422-8.

10. Kauppinen R, Sintonen H, Tukiainen H. One-year economic evaluation of intensive vs conventional patient education and supervision for self-management of new asthmatic patients. Respir Med 1998;92:300-7.

11. Greineder DK, Loane KC, Parks P. A randomized controlled trial of a pediatric asthma outreach program. J Allergy Clin Immunol 1999; 103:436-40.

12. Wesseldine LJ, McCarthy P, Silverman M. Structured discharge procedure for children admitted to hospital with acute asthma: a randomised controlled trial of nursing practice. Arch Dis Child 1999;80:110-4.

13. Evans R III, Gergen PJ, Mitchell H, et al. A randomized clinical trial to reduce asthma morbidity among inner-city children: results of the National Cooperative Inner-City Asthma Study. J Pediatr 1999;135:332-8.

14. Kelly CS, Morrow AL, Shults J, Nakas N, Strope GL, Adelman RD. Outcomes evaluation of a comprehensive intervention program for asthmatic children enrolled in Medicaid. Pediatrics 2000;105:1029-35.

15. Kelly CS, Shield SW, Gowen MA, Jaganjac N, Andersen CL, Strope GL. Outcomes analysis of a summer asthma camp. J Asthma 1998;35:165-71.

16. Irvine L, Crombie IK, Clark RA, et al. Advising parents of asthmatic children on passive smoking: randomised controlled trial. BMJ 1999;318:1456-9.

17. Fall AJ, Henry RL, Hazell T. The use of an interactive computer program for the education of parents of asthmatic children. J Paediatr Child Health 1998;34:127-30.

18. Turner MO, Taylor D, Bennett R, Fitzgerald JM. A randomized trial comparing peak expiratory flow and symptom self-management plans for patients with asthma attending a primary care clinic. Am J Respir Crit Care Med 1998;157:540-6.

19. Côté J, Cartier A, Malo JL, Rouleau M, Boulet LP. Compliance with peak expiratory flow monitoring in home management of asthma. Chest 1998;113:968-72.

20. Lopez-Vina A, del Castillo-Arevalo E. Influence of peak expiratory flow monitoring on an asthma self-management education programme. Respir Med 2000;94:760-6.

21. Kennedy DT, Chang Z, Small RE. Selection of peak flow meters in ambulatory asthma patients: a review of the literature. Chest 1998; 114:587-92.

22. Rushford N, Tiller JW, Pain MC. Perception of natural fluctuations in peak flow in asthma: clinical severity and psychological correlates. J Asthma 1998;35:251-9.

23. Eid N, Yandell B, Howell L, Eddy M, Sheikh S. Can peak expiratory flow predict airflow obstruction in children with asthma? Pediatrics 2000;105:354-8.

24. Strayhorn V, Leeper K, Tolley E, Self T. Elevation of peak expiratory flow by a "spitting" maneuver: measured with five peak flowmeters. Chest 1998;113:1134-6.

25. Koyama H, Nishimura K, Ikeda A, Tsukino M, Izumi T. Comparison of four types of portable peak flow meters (Mini-Wright, Assess, Pulmo-graph and Wright Pocket meters). Respir Med 1998;92:505-11. 
26. Richter K, Kanniess F, Mark B, Jorres RA, Magnussen H. Assessment of accuracy and applicability of a new electronic peak flow meter and asthma monitor. Eur Respir J 1998;12:457-62.

27. Finkelstein J, Cabrera MR, Hripcsak G. Internet-based home asthma telemonitoring: can patients handle the technology? Chest 2000;117:148-55.

28. Reddel HK, Ware SI, Salome CM, Jenkins CR, Woolcock AJ. Pitfalls in processing home electronic spirometric data in asthma. Eur Respir J 1998;12:853-8.

29. Apter AJ, Reisine ST, Affleck G, Barrows E, ZuWallack RL. Adherence with twice-daily dosing of inhaled steroids. Socioeconomic and health-belief differences. Am J Respir Crit Care Med 1998;157:1810-7.

30. Neville RG, Higgins BG. Issues at the interface between primary and secondary care in the management of common respiratory disease. 3: Providing better asthma care: what is there left to do? Thorax 1999;54:813-7.

31. Eaton T, Withy S, Garrett, JE, Mercer J, Whitlock RML, Rea HH. Spirometry in primary care practice: the importance of quality assurance and the impact of spirometry workshops. Chest 1999;116:416-23.

32. Ferguson GT, Enright PL, Buist AS, Higgins MW. Office spirometry for lung health assessment in adults: A consensus statement from the National Lung Health Education Program. Chest 2000;117:1146-61.

\section{RECOMMENDATIONS ON THE USE OF INHALED CORTICOSTEROIDS IN ADULTS Pierre Ernst}

\section{Efficacy}

The Canadian Asthma Consensus Report, 1999 (1) stated that inhaled corticosteroids offer the best option for the initial anti-inflammatory therapy of asthma. This statement is further supported by the recent study by Suissa and colleagues (2), who examined asthma death among residents of Saskatchewan aged five to 44 years. A dose-dependent reduction in asthma mortality with increasing use of inhaled corticosteroids was reported. The rate of death from asthma was reduced by approximately $50 \%$ with the use of six or more canisters of inhaled corticosteroids during a 12-month period. Of note was that $93 \%$ of the canisters dispensed were low dose beclomethasone (200 inhalations of $50 \mu \mathrm{g}$ each).

Because Beclovent and Becloforte (beclomethasone dipropionate, Glaxo Wellcome Inc, Canada) are no longer available, fluticasone propionate (Flovent, Glaxo Wellcome Inc, Canada) has become the most frequently prescribed inhaled corticosteroid in Canada. It must be remembered that, on a microgram basis, fluticasone is twice as potent as beclomethasone, so that the usual maximal dose of fluticasone is $1000 \mu \mathrm{g} /$ day. The equivalent maximal daily dose of budesonide (Pulmicort, AstraZeneca, Canada) is $1600 \mu \mathrm{g}$. Qvar (3M Pharmaceuticals, Canada) is a new formulation of beclomethasone in which the standard chlorofluorohydrocarbon propellant has been replaced by the environmentally friendlier HFA-134a propellant. This product has recently been introduced to the Canadian market. In light of its better lung deposition, it is recommended by the manufacturer for use without a spacer device. Its potency on a microgram per microgram basis is at least twice that of the chlorofluorocarbon (CFC) formulation of beclomethasone so that the usual maximal daily dose is $800 \mu \mathrm{g} / \mathrm{day}$. The very fine particle size produced with Qvar also promotes greater peripheral deposition of the medication. This may be of potential therapeutic benefit in adults (3). Information obtained from Glaxo Wellcome Inc suggests that the HFA formulation of fluticasone, which should be available soon (Flovent HFA, Glaxo Wellcome Inc, Canada), will be interchangeable with the current CFC formulation on a microgram per microgram basis.

\section{Safety issues}

The principal adverse effect of concern with inhaled corticosteroids for adults is the potential for promoting osteoporosis and the subsequent excess risk of fractures. While several studies $(4,5)$ examining bone density after one and two years of follow-up have been reassuring, a recent study by Wong et al (6) probably provides a more accurate picture of the risk encountered in day to day practice. A small but significant decrease in bone mineral density among young adults of both sexes with relatively mild asthma who were observed for an average of six years was reported. The effect was of sufficient size and occurred at doses commonly used, so that a significant excess of fractures would be expected as these patients age. An increase in actual fracture risk, however, remains to be shown.

While suppression of adrenal function can be shown with high doses of inhaled corticosteroids, this has not yet been shown to be of clinical relevance (7). Of interest is a case report of laryngeal aspergillosis in a patient receiving $2 \mathrm{mg} /$ day of fluticasone. This can be added to the differential diagnosis of hoarseness among patients on inhaled corticosteroids (8).

\section{REFERENCES}

1. Boulet LP, Becker A, Bérubé D, Beveridge R, Ernst P, on behalf of the Canadian Asthma Consensus Group. Canadian Asthma Consensus Report, 1999. CMAJ 1999;161(11 Suppl):S1-61.

2. Suissa S, Ernst P, Benayoun S, Baltzan M, Cai B. Low-dose inhaled corticosteroids and the prevention of death from asthma. N Engl J Med 2000;343:332-6.

3. Goldin JG, Tashkin DP, Kleerup EC, et al. Comparative effects of hydrofluoroalkane and chlorofluorocarbon beclomethasone dipropionate inhalation on small airways: assessment with functional helical thin-section computed tomography. J Allergy Clin Immunol 1999;104:S258-67.

4. Medici TC, Grebski E, Hacki M, Ruegsegger P, Maden C, Efthimiou J. Effect of one year treatment with inhaled fluticasone propionate or beclomethasone dipropionate on bone density and bone metabolism: a randomised parallel group study in adult asthmatic subjects. Thorax 2000;55:375-82.

5. Li JT, Ford LB, Chervinsky P, et al. Fluticasone propionate powder and lack of clinically significant effects on hypothalamic-pituitary-adrenal axis and bone mineral density over 2 years in adults with mild asthma. J Allergy Clin Immunol 1999;103:1062-8.

6. Wong CA, Walsh LJ, Smith CJ, et al. Inhaled corticosteroid use and bone-mineral density in patients with asthma. Lancet 2000;355:1399-403.

7. Lipworth BJ. Systemic adverse effects of inhaled corticosteroid therapy: A systematic review and meta-analysis. Arch Intern Med 1999;159:941-55.

8. Fairfax AJ, David V, Douce G. Laryngeal aspergillosis following high dose inhaled fluticasone therapy for asthma. Thorax 1999;54:860-1.

\section{THE USE OF INHALED GLUCOCORTICOSTEROIDS IN CHILDREN WITH PERSISTENT ASTHMA}

\section{F Estelle $R$ Simons}

Since the 1999 Canadian Asthma Consensus Report appeared, published studies have directly addressed several important issues in persistent childhood asthma. These include the following: airway inflammation in asymptomatic children; inhaled glucocorticosteroid dose-response 
and/or dose-interval studies; inhaled glucocorticosteroid comparison and additivity studies with other classes of medication; and the effect of inhaled glucocorticosteroids on linear growth.

\section{Airway inflammation in the absence of symptoms}

In infants and children, it is ethically difficult to justify bronchoscopy for research purposes; consequently, there is a dearth of published information on the inflammatory cell and mediator content of bronchoalveolar lavage (BAL) fluid in the pediatric population. Using a nonbronchoscopic BAL procedure in 161 children presenting for elective surgery, Ennis et al (1) have confirmed that there is ongoing activation of airway eosinophils in childhood atopic asthma even during relatively asymptomatic periods. They reported that the eosinophil cationic protein concentrations in BAL fluid from atopic children with asthma were significantly higher than the eosinophil cationic protein concentrations in BAL fluid from healthy control children. BAL histamine concentrations were elevated compared with those found in healthy control subjects, and additionally, were higher in atopic children with asthma than in atopic children without asthma.

\section{Inhaled glucocorticosteroid dose-response and/or dose-interval studies}

The lack of studies of inhaled glucocorticosteroid dose response and/or dose frequency in children with persistent asthma has recently been addressed in large, prospective, randomized, double-blind, placebo controlled clinical trials. The dose-response 'curve' for fluticasone propionate administered twice daily through a Babyhaler spacer (GlaxoWellcome Ltd, Ireland) to infants and toddlers with an average age of 28 months was relatively flat. The percentage of patients with one or more exacerbations was significantly lower in those treated with fluticasone $200 \mu \mathrm{g} /$ day $(20 \%)$ or $100 \mu \mathrm{g} /$ day group (26\%) than in those treated with placebo (37\%), accompanied by significant improvements in overall asthma control in both active treatment groups (2).

In a study of budesonide administered with a Turbuhaler (AstraZeneca Canada Inc, Canada) to children aged five to 15 years with mild asthma (PEF and FEV 1 at least $90 \%$ of personal best at time of entry), once-daily treatment appeared to be as effective as twice-daily treatment (3). In 12 -week budesonide suspension studies in young children (six months to eight years of age), once-daily dosing was found to be significantly more effective than placebo, although perhaps not as effective as twice-daily dosing $(4,5)$.

\section{Comparison studies and addition to other medications}

In the landmark Children's Asthma Management Project (CAMP) study (a prospective, randomized, double-blind, parallel-group, five-year comparative study of twice-daily budesonide $200 \mu \mathrm{g}$, nedocromil $8 \mathrm{mg}$ or placebo in 1041 children), budesonide was found to be superior to placebo with regard to the following outcomes: significantly smaller decline in the prebronchodilator $\mathrm{FEV}_{1}$ to $\mathrm{FVC}$ ratio, reduced AHR to methacholine, fewer hospitalizations, fewer urgent care visits for asthma, reduced need for 'rescue' beta2-agonists and fewer courses of prednisone. Nedocromil was superior to placebo only with regard to significantly reduced urgent care visits for asthma and fewer courses of prednisone (6).

Although the beneficial effects of adding a long acting beta2-adrenergic agonist such as salmeterol or formoterol, or a leukotriene modifier such as montelukast or zafirlukast (or even theophylline!) to an inhaled glucocorticosteroid have been clearly documented in adults with persistent asthma, until now there has been a paucity of such studies in children.

The addition of salmeterol $50 \mu \mathrm{g}$ twice daily to fluticasone propionate $100 \mu \mathrm{g}$ twice daily combined in the same Diskus as Advair 50 (Glaxo Wellcome Inc, Canada) was slightly, although not significantly, more effective in controlling asthma in children than the same medications administered in separate Diskus inhalers (7). Regularly adding montelukast $5 \mathrm{mg}$ daily to budesonide $200 \mu \mathrm{g}$ twice daily has also been reported to be more effective than adding placebo to budesonide in children with regard to improvement in pulmonary function and reduction of asthma exacerbations (8).

\section{Linear growth}

The potential adverse effect of inhaled glucocorticosteroids on linear growth remains an important concern. In 52 weeks of open follow-up to the budesonide studies described previously $(4,5)$, the mean growth velocity of the infants and children who had been treated with inhaled glucocorticosteroids before study entry did not differ in the steroid- and placebo-treated groups $(4,9)$. However, in one of these studies, in which only inhaled glucocorticosteroid-naive children were enrolled, boys but not girls treated with steroids had a small but significantly reduced growth velocity compared with those treated with placebo $(5,9)$.

In the CAMP study, the children treated with budesonide had a significantly reduced height increase compared with those treated with nedocromil or placebo. This $1.1 \mathrm{~cm}$ difference became apparent soon after starting budesonide treatment and was not progressive during the five consecutive years of regular budesonide treatment (6). In a 20 -week prospective, randomized pediatric study of high dose inhaled glucocorticosteroids, which was not placebo controlled, linear growth was slower in those taking budesonide $800 \mu \mathrm{g}$ total daily dose than in those taking fluticasone propionate $400 \mu \mathrm{g}$ daily. There were no significant differences between the groups with regard to serum cortisol levels, or hepatic or renal function (10). In a long term prospective study that was neither randomized nor placebo controlled, in which children were treated with budesonide for a mean of 9.2 years (range three to 13 years), normal adult height was attained, although growth rates were significantly reduced during the first years of treatment (11). In a recent meta-analysis of the effect of glucocorticosteroids on linear growth in children with mild to moderate asthma, fluticasone propionate decreased growth velocity by only $0.43 \mathrm{~cm} /$ year, in contrast to beclomethasone dipropionate, which decreased it by $1.51 \mathrm{~cm} /$ year (12). 


\section{Summary}

We continue to recommend inhaled glucocorticosteroids as the mainstay of treatment for persistent asthma in children, except for those whose disease is so mild that they only require infrequent, as-needed beta2-agonist treatment. Glucocorticosteroid dosing should be individualized, and the minimum effective dose should be used. A steroid-sparing medication, such as salmeterol or montelukast, should be added to the treatment regimen of children requiring $400 \mu \mathrm{g} / \mathrm{day}$ budesonide, $200 \mu \mathrm{g} /$ day fluticasone propionate or equivalent doses of other inhaled glucocorticosteroids. Regular monitoring of asthma outcomes, including intermittent measurement of lung function using spirometry and measurement of linear growth using a calibrated stadiometer, is essential for the optimal care of the child with persistent asthma.

\section{REFERENCES}

1. Ennis M, Turner G, Schock BC, et al. Inflammatory mediators in bronchoalveolar lavage samples from children with and without asthma. Clin Exp Allergy 1999;29:362-6.

2. Bisgaard H, Gillies J, Groenewald M, Maden C. The effect of inhaled fluticasone propionate in the treatment of young asthmatic children: a dose comparison study. Am J Respir Crit Care Med 1999;160:126-31.

3. Möller C, Strömberg L, Oldaeus G, Arweström E, Kjellman M. Efficacy of once-daily versus twice-daily administration of budesonide by Turbuhaler in children with stable asthma. Pediatr Pulmonol 1999;28:337-43.

4. Baker JW, Mellon M, Wald J, Welch M, Cruz-Rivera M, Walton-Bowen K. A multiple-dosing, placebo-controlled study of budesonide inhalation suspension given once or twice daily for treatment of persistent asthma in young children and infants. Pediatrics 1999;103:414-21.

5. Kemp JP, Skoner DP, Szefler SJ, Walton-Bowen K, Cruz-Rivera M, Smith JA. Once-daily budesonide inhalation suspension for the treatment of persistent asthma in infants and young children. Ann Allergy Asthma Immunol 1999;83:231-9.

6. Childhood Asthma Management Program Research Group. Long-term effects of budesonide or nedocromil in children with asthma. N Engl J Med 2000;343:1054-63.

7. Van den Berg NJ, Ossip MS, Hederos CA, Anttila H, Ribeiro BL, Davies PI. Salmeterol/fluticasone propionate $(50 / 100 \mu \mathrm{g})$ in combination in a Diskus inhaler (Seretide) is effective and safe in children with asthma. Pediatr Pulmonol 2000;30:97-105.

8. Simons FER, for the Pediatric Montelukast-Budesonide Investigators. Montelukast added to budesonide in children with persistent asthma. A multicenter, randomized, double-blind, crossover study. J Pediatr. (In press)

9. Skoner DP, Szefler SJ, Welch M, Walton-Bowen K, Cruz-Rivera M, Smith JA. Longitudinal growth in infants and young children treated with budesonide inhalation suspension for persistent asthma. J Allergy Clin Immunol 2000;105:259-68.

10. Ferguson AC, Spier S, Manjra A, Versteegh FGA, Mark S, Zhang P Efficacy and safety of high-dose inhaled steroids in children with asthma: a comparison of fluticasone propionate with budesonide. J Pediatr 1999; 134:422-7.

11. Agertoft L, Pedersen S. Effect of long-term treatment with inhaled budesonide on adult height in children with asthma. N Engl J Med 2000;343:1064-9.

12. Sharek PJ, Bergman DA. The effect of inhaled steroids on the linear growth of children with asthma: a meta-analysis. Pediatrics 2000;106:e8.

\section{SHORT AND LONG ACTING BETA2-AGONISTS Tony R Bai, Malcolm Sears}

Some controversies that were current at the time of the 1999 guidelines led to further research related to the safety and efficacy of short and long acting beta2-agonist bronchodilators.

\section{Safety of short acting beta2-agonists}

Regular terbutaline use has no adverse effects on the clinical response to inhaled corticosteroids in mild to moderate asthma, although sputum eosinophil counts increased with terbutaline treatment alone, consistent with some previous studies (1). Increased allergen-induced mast cell degranulation is seen after 10-day regular monotherapy with salbutamol (2), emphasizing again that regular short acting beta2-agonist monotherapy cannot be recommended in atopic asthma. Furthermore, PEF reduction during regular monotherapy with salbutamol seems to be genetically influenced (3).

\section{Differential effects of enantiomers (isomers) of beta-agonists}

Purified enantiomer-selective products of salbutamol are now commercially available, and similar products of other beta2-agonists are in development. Bronchodilator action resides in the R enantiomer. Advantages to using products containing only the $\mathrm{R}$ enantiomer have been proposed, but the clinical relevance is unclear (4).

\section{Effect of changing from CFC to HFA propellants}

Most of the current short and long acting beta2-agonist bronchodilators are or will soon be available in HFA preparations. There is no evidence that the new propellant significantly changes key aspects of the pharmacokinetics or pharmacodynamics of beta-agonist action, although individual products show differing properties such as spray speed and less dose-to-dose variability (5).

\section{Impact of long acting beta-agonists on response to short acting beta-agonists}

When studied under laboratory conditions, regular treatment with long acting beta-agonists can produce short acting beta-agonist subsensitivity, an effect partially prevented by a bolus dose of high dose inhaled or systemic corticosteroid (6). Low doses of inhaled corticosteroids may not be as effective at preventing this effect. A subsensitivity effect is evident in the Formoterol And Corticosteroids Establishing Therapy (FACET) study's run-in period, but was not evident in smaller studies (7). However, large scale clinical trials indicate that there is continued adequate bronchodilator response to short acting beta-agonists, despite regular, twice-daily use of long acting beta-agonists, including during episodes of acute asthma $(8,9)$.

\section{Comparison of salmeterol and formoterol efficacy and safety}

Neither salmeterol nor formoterol has been shown to have major adverse effects in patients with asthma when used in conjunction with inhaled corticosteroids. Airway responsiveness is not increased after six months of therapy with formoterol (8). New data have confirmed the ability of salmeterol to reduce inhaled corticosteroid doses (10), consistent with previous data for both salmeterol and formoterol. These two compounds cannot be regarded as interchangeable: the greater 
maximal efficacy of formoterol translates into substantially greater bronchoprotective effects than with salmeterol (11). Formoterol is rapid acting and can be used as rescue therapy (7). Tattersfield et al (12) have shown that, compared with the short acting beta-agonist terbutaline, formoterol used for 'as-needed' rescue therapy delays the time to exacerbation, with no evidence of adverse effects in terms of exaggerated decline in potassium, electrocardiographic Q-TC changes or hyperglycemia. Reductions in serum potassium with formoterol are of no greater duration than with terbutaline, possibly because the long acting depot site of inhaled formoterol is only in the airways, not in other tissues (13). The greater cost of using formoterol as rescue therapy instead of a short acting beta2-agonist needs to be evaluated in relation to the potential for benefit from decreased exacerbations. There are also some other unexplained differences in the pharmacological profile of the two long acting beta2-agonist compounds (14).

\section{Comparison of long acting beta2-agonists with leukotriene receptor antagonists and theophylline as add-on therapies}

In patients with moderate to severe asthma receiving inhaled corticosteroids, long acting beta2-agonists have been shown to be superior to zafirlukast (15) and theophylline (16) as add-on therapy. Tolerance does develop to some bronchoprotective actions of salmeterol and probably formoterol, for example, against exercise challenge or methacholine challenge, whereas this has not been shown with the leukotriene receptor antagonists (17). Further comparisons of long acting beta2-agonists and montelukast as second-line therapy in patients not controlled on moderate doses of inhaled corticosteroids are recommended.

\section{Do long acting beta2-agonists have anti-inflammatory properties or potentiate the anti-inflammatory effects of corticosteroids?}

Laboratory data show both pro- and anti-inflammatory effects of long acting beta2-agonists. Long acting beta2-agonists have been shown to reduce inflammatory cell influx into the airways, an effect that is probably secondary to an effect on venular permeability $(18,19)$, although an effect on sensory nerves is also possible. Formoterol, but not salmeterol, has an in vivo mast cell-stabilizing effect, as shown by comparing adenosine monophosphate and histamine airway responsiveness, probably secondary to the greater beta2-receptor occupancy on mast cells by the full agonist formoterol (20). The latter property may translate into a greater effect of formoterol on allergen- and exercise-induced exacerbations, although direct comparative studies are lacking. Conversely, long acting beta2-agonists can block the apoptotic effect of steroids on eosinophils, potentially prolonging eosinophil action in the airways, which may be deleterious (21). Overall, the clinical relevance of these studies requires further evaluation. The National Heart, Lung, and Blood (NHLBI) studies (10) suggest that long acting beta2-agonists have little anti-inflammatory benefit when not used in combination with inhaled corticosteroids; in addition, these stud- ies show that patients with persistent asthma that is well controlled with low dose inhaled corticosteroids cannot be switched to monotherapy with salmeterol without an increased risk of exacerbations that is not different from placebo.

Long acting beta2-agonists, more so than short acting beta2-agonists, may be able to facilitate the binding of glucocorticoid to the glucocorticoid receptor and the subsequent translocation to the cell nucleus so that the anti-inflammatory action in the airway is potentiated (22). This finding provides a potential mechanism for the inhaled corticosteroid dose reductions shown in the FACET (7) and other studies. In this sense, long acting beta2-agonists might be regarded as antiinflammatory or 'steroid facilitatory' agents.

\section{Do long acting beta2-agonists 'mask' worsening asthma?}

Patients may present for treatment with a greater degree of sputum eosinophilia if they are on long acting beta2-agonists when an exacerbation begins (23). The clinical relevance of this finding is, however, uncertain, because beta-agonists have been shown to reduce the dose of inhaled corticosteroids required to maintain control and to increase the time to exacerbation (12). Furthermore, in patients on maintenance doses of inhaled corticosteroids, treatment with formoterol, compared with placebo, does not increase sputum eosinophilia at presentation of exacerbations (24). The NHLBI study also shows no tendency for increased sputum inflammation on long acting beta2-agonist monotherapy. An analysis of the nature of exacerbations in the FACET study has shown no tendency for formoterol to alter the time course or severity of exacerbations (25).

\section{Combination therapies of long acting beta2-agonists and inhaled corticosteroids in asthma}

Devices combining fluticasone and salmeterol are now available, and combinations of formoterol and budesonide will be available in Canada shortly. These products combine complementary properties of two established asthma therapies. The available evidence suggests that combination devices can replace two separate inhalers and, thus, simplify therapy (26). However, there is no evidence of a superior effect from the combination device. Potential advantages of combination therapy are improved compliance, as yet unproven, and savings in prescription fees. Disadvantages include lack of flexibility when there is a need to increase doses of inhaled steroids during exacerbations, and the potential for high doses of both compounds being delivered inappropriately when the device is not used as instructed.

\section{Summary}

Short acting beta2-agonists should be used only as needed and not as monotherapy, except for very occasional, minor symptoms. Long acting beta2-agonists, used in conjunction with inhaled corticosteroids, provide improved symptom control compared with inhaled corticosteroids alone, and reduce the occurrence of exacerbations; they have little, if any, 
anti-inflammatory activity, and should not be used as monotherapy. Formoterol and salmeterol have differing pharmacological properties, which may suggest differing clinical uses (eg, formoterol may be useful for as-needed treatment given its fast onset of action). Combination long acting beta2-agonist and inhaled corticosteroid inhalers may simplify therapy and enhance compliance.

\section{REFERENCES}

1. Aldridge RE, Hancox RJ, Taylor DR, et al. Effects of terbutaline and budesonide on sputum cells and bronchial hyperresponsiveness in asthma. Am J Respir Crit Care Med 2000;161:1459-64.

2. Swystun VA, Gordon JR, Davis EB, Zhang X, Cockcroft DW. Mast cell tryptase release and asthmatic responses to allergen increase with regular use of salbutamol. J Allergy Clin Immunol 2000;106:57-64.

3. Israel E, Drazen JM, Liggett SB, et al. The effect of polymorphisms of the beta2-adrenergic receptor on the response to regular use of albuterol in asthma. Am J Respir Crit Care Med 2000;162:75-80.

4. Nelson HS. Clinical experience with levalbuterol. J Allergy Clin Immunol 1999; 104:S77-84.

5. Muir JF. An overview of the clinical efficacy of HFA-BDP in asthma. Respir Med 2000;94(Suppl D):S17-20.

6. Lipworth BJ, Aziz I. Bronchodilator response to albuterol after regular formoterol and effects of acute corticosteroid administration. Chest 2000;117:156-62.

7. Ekstrom T, Ringdal N, Tukiainen P, Runnerstrom E, Soliman S. A 3-month comparison of formoterol with terbutaline via turbuhaler. A placebo-controlled study. Ann Allergy Asthma Immunol 1998;81:225-30.

8. FitzGerald JM, Chapman KR, Della Cioppa G, on behalf of the Canadian FO/OD1 Study Group. Sustained bronchoprotection, bronchodilatation, and symptom control during regular formoterol use in asthma of moderate or greater severity. J Allergy Clin Immunol 1999; 103:427-35.

9. Korosec M, Novak RD, Myers E, Skowronski M, McFadden ER. Salmeterol does not compromise the bronchodilator response to albuterol during acute episodes of asthma. Am J Med 1999;107:209-13.

10. Tattersfield AE, Lofdahl CG, Postma DS, et al. Comparison of formoterol and terbutaline for as-needed treatment of asthma: a randomised trial. Lancet 2001;357:257-61.

11. Palmqvist M, Ibsen T, Mellen A, Lotvall J. Comparison of the relative efficacy of formoterol and salmeterol in asthmatic patients. Am J Respir Crit Care Med 1999;160:244-9.

12. Tattersfield A, Lofdahl C, Postma D, et al. On demand treatment: comparison of formoterol and terbutaline in moderate asthma. Am J Respir Crit Care Med 1999;159:A636. (Abst)

13. Totterman KJ, Huhti L, Sutinen E, et al. Tolerability to high doses of formoterol and terbutaline via Turbuhaler for 3 days in stable asthmatic patients. Eur Respir J 1998;12:573-9.

14. Guhan AR, Cooper S, Oborne J, Lewis S, Bennett J, Tattersfield AE. Systemic effects of formoterol and salmeterol: a dose-response comparison in healthy subjects. Thorax 2000;55:650-6.

15. Busse W, Nelson H, Wolfe J, Kalberg C, Yancey SW, Rickard KA. Comparison of inhaled salmeterol and oral zafirlukast in patients with asthma. J Allergy Clin Immunol 1999;103:1075-80.

16. Davies B, Brooks G, Devoy M. The efficacy and safety of salmeterol compared to theophylline: meta-analysis of nine controlled studies. Respir Med 1998;92:256-63.

17. Edelman JM, Turpin JA, Bronsky EA, et al, for the Exercise Study Group. Oral montelukast compared with inhaled salmeterol to prevent exercise-induced bronchoconstriction. A randomized, double-blind trial. Ann Intern Med 2000;132:97-104.

18. Greiff L, Wollmer P, Andersson M, Svensson C, Persson CG. Effects of formoterol on histamine induced plasma exudation in induced sputum from normal subjects. Thorax 1998;53:1010-3.

19. Wallin A, Sandstrom T, Soderberg M, et al. The effects of regular inhaled formoterol, budesonide, and placebo on mucosal inflammation and clinical indices in mild asthma. Am J Respir Crit Care Med 1999;159:79-86.

20. Nightingale JA, Rogers DF, Barnes PJ. Differential effect of formoterol on adenosine monophosphate and histamine reactivity in asthma. Am J Respir Crit Care Med 1999;159:1786-90.

21. Nielson CP, Hadjokas NE. Beta-adrenoceptor agonists block corticosteroid inhibition in eosinophils. Am J Respir Crit Care Med 1998;157:184-91.
22. Eickelberg O, Roth M, Lorx M, et al. Ligand-independent activation of the glucocorticoid receptor by $\beta_{2}$-adrenergic receptor agonists in primary human lung fibroblasts and vascular smooth muscle cells. J Biol Chem 1999;274:1005-10.

23. McIvor RA, Pizzichini E, Turner MO, Hussack P, Hargreave FE, Sears MR. Potential masking effects of salmeterol on airway inflammation in asthma. Am J Respir Crit Care Med 1998; 158:924-30.

24. Kips JC, O'Connor BJ, Inman MD, Svensson K, Pauwels RA, O'Byrne PM. A long-term study of the anti-inflammatory effect of low-dose budesonide plus formoterol versus high-dose budesonide in asthma. Am J Respir Crit Care Med 2000;161:996-1001.

25. Tattersfield AE, Postma DS, Barnes PJ, et al, for the FACET International Study Group. Exacerbations of asthma: A descriptive study of 425 severe exacerbations. Am J Respir Crit Care Med 1999;160:594-9.

26. Chapman KR, Ringdal N, Backer V, Palmqvist M, Saarelainen S, Briggs M. Salmeterol and fluticasone propionate $(50 / 250 \mu \mathrm{g})$ administered via combination Diskus inhaler: as effective as when given via separate Diskus inhalers. Can Respir J 1999;6:45-51.

\section{LEUKOTRIENE RECEPTOR ANTAGONISTS}

Francine M Ducharme, Paul O'Byrne

Recent trials have evaluated the role of antileukotriene agents as add-on therapy to inhaled corticosteroids or as single agents in the management of asthma. Other studies have examined their ability to modulate eosinophilic airway inflammation in asthma.

\section{Antileukotriene agents as single agents}

Ten randomized, controlled trials have compared antileukotriene agents (leukotriene receptor antagonists) to inhaled corticosteroids in adults with asthma (eight trials) or children (two trials), and their results are summarized in a recent Cochrane review (1). As of April 2000, two of these trials had been published in full text $(2,3)$ and eight studies were unpublished, with partial results presented as abstracts and/or posters. An 11th trial, published after the systematic review, supported its conclusion (4). Current evidence indicates that in patients with mild to moderate asthma who are symptomatic at baseline, inhaled corticosteroids are more effective than a six- to 12-week course of antileukotriene agents in improving lung function and quality of life, and in reducing symptoms, night awakenings and the use of rescue beta2-agonists. Daily oral leukotriene receptor antagonists appear comparable but not equivalent to daily inhaled corticosteroids in doses equivalent to 250 to $400 \mu \mathrm{g} / \mathrm{day}$ of beclomethasone for preventing asthma exacerbations over a 12 -week period. The higher rate of withdrawals in patients treated with antileukotrienes than in those receiving inhaled steroids is a potential source of concern. Due to the small number of trials contributing data to this systematic review, the following conclusions should be interpreted with caution and are subject to change with accumulating data.

There is no role for antileukotriene agents as a single anti-inflammatory agent in the treatment of moderate to severe asthma. Their use should be reserved for adults and children with very mild asthma who would be controlled on a low dose of inhaled steroids (less than 250 to $400 \mu \mathrm{g} / \mathrm{day}$ of beclomethasone equivalent), but are unable to adequately take their inhaled steroids due to coordination or compliance issues. 


\section{Antileukotriene agents as add-on therapy to inhaled steroids}

The possible benefit of adding leukotriene receptor antagonists to inhaled corticosteroids has also been evaluated in seven randomized, controlled trials, and is the topic of a new Cochrane systematic review (in preparation). As of August 2000, four trials were published in full text (5-8) and four trials were unpublished, with partial results presented as abstracts and/or posters (9-12). Preliminary findings suggest that for adults with chronic asthma who are well controlled on high doses of inhaled glucocorticoids, the addition of antileukotrienes to inhaled steroids may allow the dose-tapering of inhaled corticosteroids by $200 \mu \mathrm{g}$ over the next 12 weeks of treatment. There is insufficient evidence to confirm whether this corticosteroid-sparing effect of antileukotriene is truly associated with equivalent asthma control and an equivalent safety profile. The findings (5-12) also suggest that for adults with chronic asthma who are symptomatic with $\mathrm{FEV}_{1}$ greater than $50 \%$ of predicted while on high doses (more than $1200 \mu \mathrm{g}$ ) of beclomethasone, the addition of antileukotriene agents reduces by $50 \%$ the rate of exacerbations requiring systemic steroids within six weeks of treatment. There is insufficient evidence to confirm the value of antileukotrienes as add-on therapy to inhaled steroids on lung function, symptoms, hospital admission, indices of inflammation and adverse effects. No pediatric trials are available.

Thus, antileukotriene agents may be considered as add-on therapy in adults who are not well controlled on or experienced significant side effects with high doses of inhaled steroids.

\section{Antileukotriene agents versus long acting beta2-agonists as add-on therapy to inhaled steroids}

A few randomized, controlled trials comparing inhaled, long acting beta2-agonists to antileukotriene agents as add-on therapy to inhaled corticosteroids have been published in abstract form only. The evidence is currently insufficient to make firm recommendations regarding the choice of add-on therapy.

\section{Effect of antileukotrienes on inflammatory markers}

The cysteinyl leukotriene LTE4 has been shown to cause eosinophilic airway inflammation (13); recently published studies have shown that leukotriene receptor antagonists or synthesis inhibitors can attenuate the blood $(6,14)$ and airway eosinophilia (15) associated with poorly controlled asthma, and reduce airway inflammation associated with allergeninduced airway responses (16). These results confirm that the cysteinyl leukotrienes and bronchoconstrictor mediators are inflammatory, and support the concept that leukotriene receptor antagonists can be considered as an anti-inflammatory therapy for asthma.

These data reinforce the classification of the leukotriene receptor antagonists in the management of asthma in the 1999 Asthma Consensus Guidelines as drugs that may be useful as additional therapy to inhaled corticosteroids; they may also be considered as first-line therapy in patients with mild asthma who cannot or will not use the most effective therapy, which is the use of inhaled corticosteroids.

\section{REFERENCES}

1. Ducharme FM, Hicks GC. Anti-leukotriene agents compared to inhaled corticosteroids in the management of recurrent and/or chronic asthma. In: The Cochrane Library, Issue 3, 2000. Oxford: Update Software Limited, 2000.

2. Malmstrom K, Rodriguez-Gomez G, Guerra J, et al, for the Montelukast/Beclomethasone Study Group. Oral montelukast, inhaled beclomethasone, and placebo for chronic asthma. A randomized, controlled trial. Ann Intern Med 1999;130:487-95.

3. Boulet LP, Laviolette M, Boucher S, Knight A, Hebert J, Chapman KR. A twelve-week comparison of salmeterol and salbutamol in the treatment of mild-to-moderate asthma: a Canadian multicenter study. J Allergy Clin Immunol 1997;99:13-21.

4. Bleecker ER, Welch MJ, Weinstein SF, et al. Low-dose inhaled fluticasone propionate versus oral zafirlukast in the treatment of persistent asthma. J Allergy Clin Immunol 2000;105:1123-9.

5. Tamaoki J, Kondo M, Sakai N, et al, for the Tokyo Joshi-Idai Asthma Research Group. Leukotriene antagonist prevents exacerbation of asthma during reduction of high-dose inhaled corticosteroid. Am J Respir Crit Care Med 1997; 155:1235-40.

6. Laviolette M, Malmstrom K, Lu S, et al, for the Montelukast/Beclomethasone Additivity Group. Montelukast added to inhaled beclomethasone in treatment of asthma. Am J Respir Crit Care Med 1999;160:1862-8.

7. Lofdahl CG, Reiss TF, Leff JA, et al. Randomised, placebo controlled trial of effect of leukotriene receptor antagonist, montelukast, on tapering inhaled corticosteroids in asthmatic patients. BMJ 1999;319;87-90.

8. Virchow JC, Prasse A, Naya I, Summerton L, Harris A. Zafirlukast improves asthma control in patients receiving high-dose inhaled corticosteroids. Am J Respir Crit Care Med 2000;162:578-85.

9. Ringdal N, White M, Harris A. Addition of zafirlukast (Accolate) compared with a double-dose of inhaled corticosteroids in patients with reversible airways obstruction symptomatic on inhaled corticosteroids. Am J Respir Crit Care Med 1999:159:639A. (Abst)

10. Laitinen LA, Zetterstrom O, Holgate ST, Binks S, Whitney JG. Effects of Accolate in permitting reduced therapy with inhaled steroids: a multicenter trial in patients with doses of inhaled steroids optimised between 800 and $2000 \mathrm{mcg}$ per day. Allergy 1995;50(Suppl 26):320. (Abst).

11. Bateman ED, Holgate ST, Binks SM, Tarna IP. A multicentre study to assess the steroid-sparing potential of Accolate. Allergy 1995;50(Suppl 26):320. (Abst)

12. Nayak AS, Anderson P, Charous BL, Williams K, Simonson S Equivalence of adding zafirlukast versus double-dose inhaled corticosteroids in asthmatic patients symptomatic on low-dose inhaled corticosteroids. J Allergy Clin Immunol 1998;101:S233. (Abst 965)

13. Laitinen LA, Laitinen A, Haahtela T, Vilkka V, Spur BW, Lee TH. Leukotriene E4 and granulocytic infiltration into asthmatic airways. Lancet 1993;341:989-90.

14. Wenzel SE, Trudeau JB, Kaminsky DA, Cohn J, Martin RJ, Westcott JY. Effect of 5-lipoxygenase inhibition on bronchoconstriction and airway inflammation in nocturnal asthma. Am J Respir Crit Care Med 1995;152:897-905.

15. Pizzichini E, Leff JA, Reiss TF, et al. Montelukast reduces airway eosinophilic inflammation in asthma: a randomized, controlled trial. Eur Respir J 1999;14:12-8.

16. Calhoun WJ, Lavins BJ, Minkwitz MC, Evans R, Gleich GJ, Cohn J. Effect of zafirlukast (Accolate) on cellular mediators of inflammation: bronchoalveolar lavage fluid findings after segmental allergen challenge. Am J Respir Crit Care Med 1998;157:1381-9.

\section{ADDITIONAL THERAPIES} Rick Hodder

For the purposes of this update, the discussion of additional or adjuvant therapies for asthma management will be restricted to nonsteroidal, inhaled anti-inflammatory agents (disodium cromoglycate [DSCG], nedocromil sodium and 
ketotifen); anticholinergic drugs; theophylline and its derivatives; and new and emerging therapies.

\section{Nonsteroidal agents: DSCG, nedocromil sodium and ketotifen}

Since the publication of the Canadian Asthma Consensus Report in November 1999, there have been few new developments in the use of nonsteroidal anti-inflammatory agents. Clinical trials continue to confirm the efficacy of DSCG in the symptomatic and prophylactic management of mild asthma (1-3), although inhaled corticosteroids are more effective for chronic, persistent asthma and even for episodic viral wheeze in young children (4). New evidence suggesting a possible oral corticosteroid-sparing effect of DSCG in adults with corticosteroid-dependent asthma has emerged. In a 12-week open, randomized trial, DSCG $16 \mathrm{mg}$ /day delivered by pressurized MDI (pMDI) or $80 \mathrm{mg} /$ day by nebulizer was associated with a small reduction in the need for oral corticosteroids in patients taking high doses of inhaled corticosteroids plus more than $5 \mathrm{mg}$ /day oral corticosteroids (5). However, the study did not have a placebo group, and the clinical significance of the results is not clear. There have been no published trials investigating the effect of adding DSCG as an alternative to increasing the dose of inhaled corticosteroids in poorly controlled asthma; thus, its role in this regard remains unproven.

Dosing of DSCG may be a factor in assessing clinical trials of efficacy, with the $20 \mathrm{mg} / \mathrm{mL}$ nebulizer formulation providing delivered doses higher than $2 \mathrm{mg}$ given by a pMDI, although clinical differences have not been systematically studied (6). HFA formulations of DSCG in the pMDI format have shown clinical equivalence to CFC formulations in doses of $2 \mathrm{mg}$ qid (7).

DSCG has also recently been shown to be protective against acetylsalicylic acid (ASA)-induced bronchoconstriction in challenge trials in ASA-sensitive patients with asthma, possibly through inhibition of the release of cysteinyl leukotrienes (8). However, there is no evidence that DSCG can be used to prevent life-threatening events in ASA-sensitive patients exposed to nonsteroidal anti-inflammatory drugs.

Both DSCG and nedocromil sodium are effective in the prevention of exertion-induced bronchoconstriction in patients with asthma, and a recent meta-analysis showed no clinically important difference between these two agents in this regard (9). The protective effect of nedocromil taken just before exercise does not appear to be enhanced when the drug is taken on a regular schedule as well (10).

As with theophylline, long acting beta2-agonists and leukotriene receptor antagonists, the addition of nedocromil can supplement the beneficial effects of regular inhaled corticosteroids for some patients with asthma (11); however, a reduction in bronchial hyper-responsiveness with nedocromil is not seen consistently.

Compared with placebo, the addition of ketotifen can improve symptoms and reduce the need for concomitant therapy with theophylline, and oral and inhaled corticosteroids, over a six-month period in some children with asthma
(12). However, at least 14 weeks of therapy were required before a clear benefit was seen, and there was no difference compared with placebo in measured lung function. In a 12-week, parallel-group trial comparing ketotifen $(2 \mathrm{mg} / \mathrm{day})$, inhaled beclomethasone (400 $\mu \mathrm{g} /$ day) and DSCG ( $8 \mathrm{mg} /$ day) in adults with asthma, all three therapies resulted in significant reductions in symptoms, bronchial hyper-responsiveness to methacholine challenge and markers of airway inflammation as assessed by bronchial biopsy (3); however, the improvements in symptoms and lung function were significantly better in the DSCG and beclomethasone groups than in the ketotifen group.

Based on this update, the current recommendations for these agents are unchanged.

\section{Anticholinergic drugs}

Anticholinergic bronchodilators are not recommended as first-line agents for the relief of bronchospasm in asthma, primarily because their onset of action is inferior to that of beta2-agonist bronchodilators. However, there is increasing evidence supporting the addition of ipratropium bromide to beta2-agonists for the emergency department treatment of acute asthma in both adults (13-16) and children $(17,18)$. Ipratropium appears to be an effective add-on whether it is delivered by nebulizer (13) or combined with salbutamol in a single pMDI (14), and the combination appears to be beneficial for up to $36 \mathrm{~h}$ following admission to hospital for acute asthma (19). A recent systematic review summarized the accumulated evidence supporting the addition of ipratropium bromide to beta2-agonist bronchodilators in the treatment of acute pediatric asthma (20).

The long acting, once a day, anticholinergic bronchodilator tiotropium bromide appears to be an effective agent in asthma (21). It would not be used as a first-line treatment for asthma, and its role as an add-on agent for difficult asthma remains to be determined. Currently, this drug is awaiting approval for release in Canada.

Based on this update, the current recommendation for anticholinergics is unchanged.

\section{Theophylline and its derivatives}

For the past 50 years, the role of theophylline in asthma management has been as a bronchodilator; however, when it is given in maximum bronchodilating doses, troublesome side effects limit its use. For this reason, and because beta2-agonists are better bronchodilators, theophylline is not considered a first-line therapy for asthma. However, over the past few years, there has been renewed interest in the use of theophylline in lower doses because of its anti-inflammatory and corticosteroid-sparing properties (22-24).

Therapy with theophylline appears to reduce the number of eosinophils and the amount of eosinophil-related markers of airway inflammation in patients with asthma (25-27), although the clinical relevance of these observations is uncertain because no comparisons of theophyllines and inhaled corticosteroids have been published in this regard. However, theophylline has been shown to reduce bronchial hyper- 
responsiveness to methacholine after two months of therapy in patients with mild, allergic asthma who are not taking inhaled corticosteroids (28), and, similar to the leukotriene receptor antagonists and inhaled, long acting beta2-agonists, theophylline can act as a corticosteroid-sparing agent when added to moderate-dose inhaled corticosteroids. Theophylline has recently been shown to reduce nasal symptoms and indices of allergic inflammation in response to nasal allergen challenge in subjects with allergic rhinitis (29). Because there appears to be a relationship between allergic rhinitis and asthma control (30), this observation suggests a possible role for theophylline in controlling asthma in this subset of patients.

Long acting theophyllines have been used to treat patients with asthma who have nocturnal symptoms, but they appear to be inferior to long acting beta2-agonist bronchodilators in this regard $(31,32)$, and in maintenance asthma therapy as well $(33,34)$. One trial has shown that the addition of theophylline has no effect on the development of tolerance to the bronchoprotective effects of salmeterol observed in patients with asthma (35).

There have been few trials comparing theophyllines with antileukotrienes, but in one recent study (36) involving 377 patients with asthma, the addition of either theophylline or zileuton (an antileukotriene not available in Canada) resulted in similar, mild improvements in $\mathrm{FEV}_{1}$ and asthma symptoms. There has been one report documenting theophylline toxicity associated with the concomitant use of zafirlukast (37), although generally this is not thought to occur.

Theophylline is a nonspecific phosphodiesterase inhibitor, but there are several isoenzymes of phosphodiesterase. The phosphodiesterase III isoenzyme appears to modulate airway smooth muscle function, and phosphodiesterase IV is important in inflammatory cells. Several phosphodiesterase IV inhibitors have been developed and are currently in phase 3 clinical trials (38).

\section{New and emerging therapies}

The combination of a beta2-agonist and a dopamine $\left(\mathrm{D}_{2}\right)$ receptor agonist is being developed as an inhaled agent to treat the symptoms of asthma. $\mathrm{D}_{2}$ agonists appear to reduce sensory nerve traffic from the airways and to alleviate some of the symptoms associated with bronchial hyper-responsiveness; these agents are currently in phase 2 trials. As noted, phase 2 and 3 clinical trials are currently underway for phosphodiesterase III and phosphodiesterase IV inhibitors. Phase 3 trials are also underway with anti-immunoglobulin $\mathrm{E}$ monoclonal antibodies (39) and with antagonists to several other mediators of airway inflammation (40).

\section{REFERENCES}

1. Krawiec ME, Wenzel SE. Inhaled nonsteroidal anti-inflammatory medications in the treatment of asthma. Respir Care Clin N Am 1999;5:555-74.

2. Konig P. The effects of cromolyn sodium and nedocromil sodium in early asthma prevention. J Allergy Clin Immunol 2000;105:S575-81.

3. Hoshino M, Nakamura Y, Sim JJ, Tomioka H. A comparative study of the effects of ketotifen, disodium cromoglycate, and beclomethasone dipropionate on bronchial mucosa and asthma symptoms in patients with atopic asthma. Respir Med 1998;92:942-50.

4. De Baets F, Van Daele S, Franckx H, Vinaimont F. Inhaled steroids compared with disodium cromoglycate in preschool children with episodic viral wheeze. Pediatr Pulmonol 1998;25:361-6.

5. Sakai H, Shimoda T, Matsuo N, et al. Comparison of three treatment regimens of inhaled sodium cromoglycate in the management of adult patients with severe, steroid-dependent asthma. Ann Allergy Asthma Immunol 1998;80:494-8.

6. Kato Y, Muraki K, Fujitaka M, Sakura N, Ueda K. Plasma concentrations of disodium cromoglycate after various inhalation methods in healthy subjects. Br J Clin Pharmacol 1999;48:154-7.

7. Furukawa C, Atkinson D, Forster TJ, et al, for the Intal Study Group. Controlled trial of two formulations of cromolyn sodium in the treatment of asthmatic patients $\geq 12$ years of age. Chest 1999;116:65-72.

8. Yoshida S, Amayasu H, Sakamoto H, et al. Cromolyn sodium prevents bronchoconstriction and urinary LTE4 excretion in aspirin-induced asthma. Ann Allergy Asthma Immunol 1998;80:171-6.

9. Kelly KD, Spooner CH, Rowe BH. Nedocromil sodium vs. cromoglycate for preventing exercise induced bronchoconstriction in asthma (Cochrane Review). In: The Cochrane Library, Issue 3, 2000. Oxford: Update Software Limited, 2000.

10. Kivity S, Onn A, Greif Y, Fireman E, Pomeranz S, Topilsky M. Nedocromil and exercise-induced asthma: acute and chronic effects. Isr Med Assoc J 1999;1:92-4.

11. Szefler SJ, Nelson HS. Alternative agents for anti-inflammatory treatment of asthma. J Allergy Clin Immunol 1998;102:S23-35.

12. Kabra SK, Pandey RM, Singh R, Seth V. Ketotifen for asthma in children aged 5 to 15 years: a randomized placebo-controlled trial. Ann Allergy Asthma Immunol 2000;85:46-52.

13. Lin RY, Pesola GR, Bakalchuk L, et al. Superiority of ipratropium plus albuterol over albuterol alone in the emergency department management of adult asthma: a randomized clinical trial. Ann Emerg Med 1998;31:208-13.

14. Rodrigo GJ, Rodrigo C. First-line therapy for adult patients with acute asthma receiving a multiple-dose protocol of ipratropium bromide plus albuterol in the emergency department. Am J Respir Crit Care Med 2000;161:1862-8.

15. Lanes SF, Garrett JE, Wentworth CE III, FitzGerald JM, Karpel JP. The effect of adding ipratropium bromide to salbutamol in the treatment of acute asthma: a pooled analysis of three trials. Chest 1998; 114:365-72.

16. Stoodley RG, Aaron SD, Dales RE. The role of ipratropium bromide in the emergency management of acute asthma exacerbation: a metaanalysis of randomized clinical trials. Ann Emerg Med 1999;34:8-18.

17. Qureshi F, Pestian J, Davis P, Zaritsky A. Effect of nebulized ipratropium on the hospitalization rates of children with asthma. N Engl J Med 1998;339:1030-5.

18. Zorc JJ, Pusic MV, Ogborn CJ, Lebet R, Duggan AK. Ipratropium bromide added to asthma treatment in the pediatric emergency department. Pediatrics 1999;103:748-52.

19. Brophy C, Ahmed B, Bayston S, Arnold A, McGivern D, Greenstone M. How long should Atrovent be given in acute asthma? Thorax 1998;53:363-7.

20. Plotnick LH, Ducharme FM. Combined inhaled anticholinergic agents and beta2-agonists for initial treatment of acute asthma in children (Cochrane Review). Cochrane Database Syst Rev 2000;4:CD000060.

21. Noveck RJ, Haynes E, Koker P, Wang Q, Souhrada JF, Witek T. Bronchodilator effect of tiotropium in moderate-severe asthmatics. Am J Respir Crit Care Med 1999;159:A625. (Abst)

22. Kips JC, Peleman RA, Pauwels RA. The role of theophylline in asthma management. Curr Opin Pulm Med 1999;5:88-92.

23. Page CP. Recent advances in our understanding of the use of theophylline in the treatment of asthma. J Clin Pharmacol 1999;39:237-40

24. Markham A, Faulds D. Theophylline. A review of its potential steroid sparing effects in asthma. Drugs 1998;56:1081-91.

25. Aizawa $H$, Iwanaga $T$, Inoue $H$, et al. Once-daily theophylline reduces serum eosinophil cationic protein and eosinophil levels in induced sputum of asthmatics. Int Arch Allergy Immunol 2000;121:123-8.

26. Horiguchi T, Tachikawa S, Kasahara J, et al. Suppression of airway inflammation by theophylline in adult bronchial asthma. Respiration 1999;66:124-7.

27. Louis R, Bettiol J, Cataldo D, Sele J, Henquet M, Radermecker M. 
Effect of a 4-week treatment with theophylline on sputum eosinophilia and sputum eosinophil chemotactic activity in steroid-naive asthmatics. Clin Exp Allergy 2000;30:1151-60.

28. Page CP, Cotter T, Kilfeather S, Sullivan P, Spina D, Costello JF. Effect of chronic theophylline treatment on the methacholine doseresponse curve in allergic asthmatic subjects. Eur Respir J 1998;12:24-9.

29. Aubier M, Neukirch C, Maachi M, et al. Effect of slow-release theophylline on nasal antigen challenge in subjects with allergic rhinitis. Eur Respir J 1998;11:1105-10.

30. Pauwels R. Influence of treatment on the nose and/or the lungs. Clin Exp Allergy 1998;28(Suppl 2):37-40.

31. Wilson AJ, Gibson PG, Coughlan J. Long acting beta-agonists versus theophylline for maintenance treatment of asthma. Cochrane Database Syst Rev 2000;2:CD001281.

32. Wiegand L, Mende CN, Zaidel G, et al. Salmeterol vs theophylline: sleep and efficacy outcomes in patients with nocturnal asthma. Chest 1999;115:1525-32.

33. Nutini S, Martini T, Righi R. Long-term treatment of asthmatic patients with salmeterol vs slow-release theophylline. Respir Med 1998;92:683-90.

34. Davies B, Brooks G, Devoy M. The efficacy and safety of salmeterol compared to theophylline: meta-analysis of nine controlled studies. Respir Med 1998;92:256-63.

35. Cheung D, Wever AM, de Goeij JA, de Graaff CS, Steen H, Sterk PJ. Effects of theophylline on tolerance to the bronchoprotective actions of salmeterol in asthmatics in vivo. Am J Respir Crit Care Med 1998;158:792-6.

36. Schwartz HJ, Petty T, Dube LM, Swanson LJ, Lancaster JF, for the Zileuton Study Group. A randomized controlled trial comparing zileuton with theophylline in moderate asthma. Arch Intern Med 1998;158:141-8

37. Katial RK, Stelzle RC, Bonner MW, Marino M, Cantilena LR, Smith LJ. A drug interaction between zafirlukast and theophylline. Arch Intern Med 1998;158:1713-5.

38. Schmidt D, Dent G, Rabe KF. Selective phosphodiesterase inhibitors for the treatment of bronchial asthma and chronic obstructive pulmonary disease. Clin Exp Allergy 1999;29(Suppl 2):99-109.

39. Milgrom H, Fick RB Jr, Su JQ, et al, for the RhuMAb-E25 Study Group. Treatment of allergic asthma with monoclonal anti-IgE antibody. N Engl J Med 1999;341:1966-73.

40. Barnes PJ. New directions in allergic diseases: mechanism-based anti-inflammatory therapies. J Allergy Clin Immunol 2000;106:5-16.

\section{DELIVERY DEVICES}

\section{Kenneth Chapman, Sheldon Spier}

Self-administered inhaled medications are the mainstay of asthma management. Incremental changes in inhalation technology have provided useful treatment alternatives, while clinical and laboratory studies have suggested methods to optimize the lung deposition of inhaled drugs.

\section{HFA formulations}

Concern that CFCs have damaged the earth's stratospheric ozone layer has led to a worldwide ban on the use of CFCs. The protocol for withdrawing CFCs was announced in 1987 (the Montreal protocol), although an exemption was made for medical uses of CFCs to allow for the development and testing of alternatives (1). Until recently, all pressurized aerosol inhalers available in Canada used CFCs as their propellant.

Today, there are two classes of antiasthma medication available in pressurized aerosol form with the alternative propellant HFA. Salbutamol is available in an HFA formulation (Airomir, 3M Pharmaceuticals, Canada) delivering the same dose of salbutamol as traditional CFC formulations (2). The change in propellant formulation has not markedly altered the performance of the inhaler. Redesign of the device has reduced the tendency for 'loss of prime' (ie, decrease in dosage delivery after the inhaler has sat unused for several hours) and for 'tail-off' (ie, dosage variability as the canister contents are nearly depleted). For patients who use their quick relief salbutamol inhaler outdoors in the winter, HFA devices will work reliably at temperatures as low as $-20^{\circ} \mathrm{C}$. For patients accustomed to CFC-containing devices, the aerosol of the HFA device will not feel as cold or as forceful. Patients may need to be reassured that the medication is pharmacologically equivalent to their previous CFC-containing device.

A pressurized aerosol, inhaled corticosteroid is also available. HFA propellant beclomethasone is available in two formulations (Qvar $50 \mu \mathrm{g} / \mathrm{puff}$ and $100 \mu \mathrm{g} / \mathrm{puff}$, $3 \mathrm{M}$ Pharmaceuticals, Canada). Although the HFA beclomethasone inhaler resembles its predecessor and delivers the same active compound, the new HFA inhaler exhibits markedly different drug delivery characteristics from the traditional CFC beclomethasone. Not only has the inhaler technology been redesigned for improved dose delivery reliability, but beclomethasone is soluble in HFA propellant. Thus, the new HFA inhaler does not contain a suspension of medication crystals in propellant but contains a clear solution of medication dissolved in the delivery vehicle. As a consequence, the spray from the HFA-containing beclomethasone inhaler consists of relatively small aerosol droplets, which are less likely to deposit in the oropharynx and more easily delivered to the peripheral or small airways of the lung. A number of studies indicate far better peripheral deposition of the HFA beclomethasone than of the CFC beclomethasone or other traditional inhaled corticosteroid devices (3). The dose equivalence between the new beclomethasone inhaler and previous beclomethasone is approximately 2:1 (4). That is, $100 \mu \mathrm{g}$ of HFA beclomethasone is roughly equivalent to $200 \mu \mathrm{g}$ of CFC beclomethasone. HFA beclomethasone appears to be roughly equivalent on a microgram per microgram basis to CFC fluticasone. There may be clinical advantages when corticosteroid is delivered to the smaller airways. Studies show that the small airways are part of the active inflammatory airway process in persistent asthma $(5,6)$. Nonetheless, no studies have shown a specific clinical benefit for delivery of drug to the smaller airways. It can be said that HFA beclomethasone provides clinical benefit equivalent to CFC beclomethasone at half the nominal dosage. Systemic side effects appear to be proportionate to clinical effects, and the large airway deposition now makes systemic effects from gastrointestinal absorption clinically unimportant. That is, there appears to be no increased risk of side effects resulting from greater peripheral deposition. Patients will not notice the deposition differences directly, but they may notice other differences with the HFA beclomethasone inhaler. Once again, the spray front is perceptibly softer and the aerosol is not as cold as with traditional CFC inhalers. The slower speed of the spray front containing finer particles may reduce patient coordination problems that are so common with current pMDIs. Studies suggest that a spacer is unnecessary with the HFA inhaler. Although there is no improvement in deposition with a spacer, and mild discoordination between activation and inhalation does not appear to affect deposition, marked 
discoordination may occur in some patients, and this can only be corrected with the use of a spacer or a powder device. This may be true particularly in young children and the elderly.

Although patients do not need to shake the HFA canister before its use, this instruction might be confusing for patients who also have a CFC inhaler that requires medication to be resuspended before inhalation. Finally, some patients report a bad taste of the HFA salbutamol aerosol formulation, although this may not apply to the other formulations (eg, HFA-beclomethasone dipropionate).

\section{Withdrawal of CFC-containing inhalers}

In 1997, Environment Canada and Health Canada consulted with the pharmaceutical industry, health care professional organizations and lay organizations to develop a strategy for the withdrawal of CFC-containing inhalers. It was agreed that CFC-containing inhalers would be withdrawn on a molecule by molecule basis. Thus, two years after the introduction of a compound in a non-CFC-pressurized formulation, all CFC-containing formulations of that same compound would be withdrawn from the marketplace. Such a withdrawal would be conditional, taking place only if several criteria were met, including the availability of sufficient manufacturing capacity to meet the demand for non-CFC products once the $\mathrm{CFC}$ predecessors were withdrawn. Physicians have not prescribed non-CFC medications preferentially, such medications have not been accorded preferential formulary status provincially and, to date, no CFC-containing inhaler has been withdrawn from the national formulary based on this agreement. Nonetheless, there is a proposed timetable for future compulsory withdrawals. It has been suggested that CFC-containing salbutamol formulations will be withdrawn by July 2001, and that all CFC-containing inhalers will be withdrawn by 2005. An Environment Canada Web site offers further information (www.ec.gc.ca/ozone/mdi).

\section{Spacer devices and holding chambers}

The combination of a spacer and a pMDI is often recommended as a less expensive, more efficient alternative to the nebulizer for the treatment of infants, patients with severe airflow limitation and the acutely ill. A spacer can, under some conditions, improve lung deposition of drugs and decrease oropharyngeal deposition, thereby improving the efficacy of an inhaled medication while decreasing some of its adverse effects. However, there is no regulatory process that monitors the stated claims of commercially available spacers. While many inhalers are likely capable of achieving the stated objectives of a spacing device, there is evidence that not all of them work well with all spacers $(7,8)$. Some available spacers may actually decrease the lung deposition of some medications. The Canadian Standards Association is working with stakeholders to develop standards for in vitro and in vivo testing of spacers that would clarify their clinical value for prescribers and patients. Until these testing standards are approved and implemented, health care professionals will depend on data provided by manufacturers and occasional peer review publications to determine if a particular spacer can be beneficial when coupled with a particular inhaled medication. Health care professionals should be alert to the potential for a spacing device or holding chamber to fail to provide the intended benefit. As for any intervention, clinical outcomes must be followed closely when adjunctive devices are added to inhalers.

The optimal method for using spacing chambers and holding devices has been described in earlier guidelines. The optimal delivery of inhaled medications to infants can be a challenge, and recent data suggest that infant behaviour during inhalation can have a significant impact on drug deposition in the lung and on the resulting clinical effect. It is somewhat obvious that crying reduces the deposition of drug in the lungs of an upset infant; it is less obvious, however, that when the infant sleeps and breathes through the nose, drug deposition in the lung can be reduced by the filtering effect of the nasal passages (9). Ideally, inhaled medication is administered while infants are awake but quiet.

\section{REFERENCES}

1. Boulet L-P. The ozone layer and metered dose inhalers. Can Respir J 1998;5:176-9.

2. Bleecker ER, Tinkelman DG, Ramsdell J, et al. Proventil HFA provides bronchodilation comparable to ventolin over 12 weeks of regular use in asthmatics. Chest 1998;113:283-9.

3. Goldin JG, Tashkin DP, Kleerup EC, et al. Comparative effects of hydrofluoroalkane and chlorofluorocarbon beclomethasone dipropionate inhalation on small airways: Assessment with functional helical thin-section computed tomography. J Allergy Clin Immunol 1999;104:S258-67.

4. Busse WW, Brazinsky S, Jacobson K, et al. Efficacy response of inhaled beclomethasone dipropionate in asthma is proportional to dose and is improved by formulation with a new propellant. J Allergy Clin Immunol 1999;104:1215-22.

5. Haley KJ, Sunday ME, Wiggs BR, et al. Inflammatory cell distribution within and along asthmatic airways. Am J Respir Crit Care Med 1998;158:565-72.

6. Hamid Q, Song YL, Kotsimbos TC, et al. Inflammation of small airways in asthma. J Allergy Clin Immunol 1997;100:44-51.

7. Ahrens R, Lux C, Bahl T, Han S-H. Choosing the metered-dose inhaler spacer or holding chamber that matches the patient's need: Evidence that the specific drug being delivered is an important consideration. J Allergy Clin Immunol 1995;96:288-94.

8. Barry PW, O'Callaghan C. Inhalational drug delivery from seven different spacer devices. Thorax 1996;51:835-40.

9. Clarke JR, Aston H, Silverman M. Delivery of salbutamol by metered dose inhaler and valved spacer to wheezy infants: effect on bronchial responsiveness. Arch Dis Child 1993;69:125-9.

\section{MANAGEMENT OF ACUTE ASTHMA IN ADULTS AND CHILDREN: EMERGENCY AND INPATIENT} Robert Beveridge, Brian Rowe

None of the recommendations made in the 1996 or 1999 guidelines for the treatment of acute asthma have been altered as a result of new evidence from randomized, controlled trials, or other types of studies or reports. The fundamental approach to diagnosis, severity assessment, drug delivery methods, choice of medications and discharge criteria are unchanged.

There are several studies and systematic reviews that increase support for the use of inhaled beta-agonists (1), inhaled anticholinergics $(2-4)$ and oral corticosteroids $(5,6)$ in the emergency department setting. Although the findings are generally positive, there are inconsistent findings for the role 
of inhaled corticosteroids in the acute setting (7-12) and after discharge $(13,14)$. This implies that disease severity, age of the patient or other factors affect the generalizability of those studies, suggesting equivalence of inhaled corticosteroids to systemic corticosteroids or additional benefit when added to oral corticosteroids. There is insufficient evidence to make definitive recommendations for the use of inhaled corticosteroids in acute asthma, but it is clear that they are effective in some situations. There is further support for the use of magnesium sulfate in severe asthma that is unresponsive to optimal management with inhaled beta-agonists and systemic corticosteroids (15). There continues to be little or no evidence to support a role for theophylline or helium-oxygen mixtures in acute asthma $(16,17)$.

The assessment of asthma severity should be determined objectively using spirometry, PEF rates or both for patients older than five years of age. Structured approaches using templates or care plans in asthma management reduce the variation in the use of oral corticosteroids, hand-held inhalation devices, objective measurements, admission rates, and lengths of stay in the emergency department and as admitted inpatients (18-20).

\section{Emergency department management}

The use of short acting beta2-agonists is the first-line therapy for the management of exacerbations. Attempts to identify optimal doses or treatment intervals to achieve maximal bronchodilation or symptom relief have not been successful $(21,22)$. Continuous treatment does not appear to have any advantage over intermittent treatment, and higher doses appear to be equivalent to lower doses with regard to affecting bronchodilation or clinical outcome $(21,22)$. There are a substantial number of patients who achieve a maximal level of bronchodilation, and additional beta2-agonist therapy only seems to cause more side effects (21). Consistent with the 1999 guidelines, it is still recommended that beta-agonists be titrated to plateau using objective assessment of airway obstruction with $\mathrm{FEV}_{1}$ and/or PEF.

There is increased support, particularly from studies in children, that anticholinergic agents should be added to beta2-agonist therapy for moderate to severe acute asthma (2-4). The systematic reviews in children (2) and adults (3) both suggest clinically important improvements associated with the combined use of these agents. In addition, large randomized, controlled trials (23) have since been completed that confirm the systematic review evidence (4).

The early use of systemic corticosteroids in acute asthma continues to be considered an important treatment choice. The debate between the use of intravenous and oral corticosteroids persists but seems to be more focused on identifying which patients actually require the intravenous route. There have been comments received on the clarity of this issue since the last guidelines update. There is no evidence in controlled trials or meta-analyses that suggests any advantage for low or high doses of intravenous corticosteroids over oral corticosteroids in moderate to severe asthma (24-26). Applying this to practice requires a clear understanding of the fact that not all levels of severity have necessarily been assessed in such a way as to confirm equivalency in all situations. For this reason, the previous two guidelines recommended intravenous corticosteroids for those who were too breathless, intubated or unable to tolerate oral medications (vomiting, dehydration). There is no evidence that this recommendation should be changed, but it should be emphasized that if patients have severe asthma, are unresponsive to treatment or there is any suspicion that oral medications will not be absorbed, the intravenous route for corticosteroids is advised.

The use of magnesium sulfate in unresponsive acute asthma has gained further support since the 1999 guidelines. There have been a number of systematic reviews $(15,27)$ that have concluded that intravenous magnesium is not only safe but also effective in those patients with severe disease. It is important to appreciate that there is no support for the routine use of this agent in the emergency management of acute asthma. The emphasis is still on the appropriate use of inhaled beta-agonists, inhaled anticholinergics and systemic corticosteroids, all guided by objective measures of oxygenation, airway obstruction and clinical status. Patients with clinically severe asthma, or in whom pulmonary function is less than $30 \%$ predicted in adults and less than $50 \%$ in children, and who exhibit a poor response to appropriately titrated bronchodilator therapy (incremental administration by MDI every 30 to $60 \mathrm{~s}$ up to 20 to 40 puffs, three doses every $20 \mathrm{~min}$ or continuous nebulization) may benefit from intravenous magnesium sulfate. This agent has been shown to be easy to use, extremely safe and inexpensive.

There is new evidence regarding the use of inhaled corticosteroids in the acute setting for patients with acute asthma (7-12,14). A recently published systematic review (8) suggests that inhaled corticosteroids, when used in conjunction with systemic corticosteroids, may reduce admissions to hospital and improve pulmonary function. However, a recent study (7) illustrates that there may be some problems in comparing oral with inhaled corticosteroids for acute asthma. In the study, patients were randomly assigned to receive, in a doubleblind fashion, inhaled corticosteroids or oral corticosteroids in addition to beta2-agonist therapy. The oral corticosteroid group performed better and was admitted to hospital less frequently. Combined with the meta-analysis, these results suggest that inhaled corticosteroids may be useful as an adjunct to systemic corticosteroids but not as a replacement choice (6).

Other agents, such as aminophylline and helium-oxygen, have been shown to be of limited value $(16,17)$. In addition, evidence for or against the use of new agents, such as leukotriene modifiers and levalbuterol, is unclear at this point. Current research should help to clarify the place of these agents before the next revision of the guidelines.

\section{Treatment after discharge}

Several studies in children and adults have been performed, identifying several factors associated with relapse after discharge $(28,29)$. However, most of the studies simply confirm the recommendations provided in the previous Canadian Association of Emergency Physicians/Canadian 
Thoracic Society guidelines. There is level I evidence for using the combination of inhaled and oral corticosteroids for the treatment of patients with asthma after discharge from the emergency department (6). There is one published randomized, controlled trial (30), and one trial result in press since the last guidelines, which do not confirm an additional benefit to adding inhaled corticosteroids; however, a systematic review favours the combination (13). Patients who present to the emergency department often exhibit many of the features associated with poorly controlled chronic asthma, making them candidates for inhaled corticosteroid therapy if they are not already taking them. Patients already receiving inhaled corticosteroids should continue to take them and have oral prednisone added, and efforts should be directed at compliance-enhancing interventions from the emergency department staff with follow-up to education programs if available. Patients not on inhaled corticosteroids should be considered for long term inhaled corticosteroid therapy in conjunction with oral prednisone after discharge. The dose and duration of inhaled and oral corticosteroids should be based on recent history of symptom control, health care use and quality of life indicators. For those patients with more severe illness, this would clearly be the optimal treatment strategy.

There are several recent publications comparing oral prednisone with very high doses of inhaled corticosteroids in acute mild asthma after discharge (13). While the systematic review failed to show significant differences in outcome, these results need to be interpreted cautiously. Although the evidence implies equivalence, inhaled corticosteroids are expensive and more difficult for patients and families to use than the traditional short course of prednisone. Consequently, the use of inhaled corticosteroids alone should be reserved for those patients with very mild asthma, and for those who refuse or cannot take oral corticosteroids. Future research should focus on this important comparison (31).

\section{Inpatient treatment}

Given all the attempts that have been made to establish an integrated approach to the 'continuum' of care, it is difficult to view inpatient management separately from management in the emergency department, acute observation units and outpatient programs. The same principles of aggressive titration of beta-agonists, systemic corticosteroids, inhaled corticosteroids, objective measurement of airflow obstruction, and emphasis on education and follow-up should be maintained. The fact that many patients with asthma only achieve a certain level of bronchodilation, regardless of the dose of inhaled beta-agonist, suggests that further work is required to ensure that medications are individually titrated for effectiveness. It is also necessary to improve our understanding of any unique treatment requirements for patients with asthma who have less reversibility in acute situations. This includes establishing optimal dose and time intervals for bronchodilators, duration of observation in emergency departments or other care settings, and admission and discharge criteria.

Several controlled trials have shown that compliance with current guidelines using structured care plans has improved, and that hospitalization rates and lengths of stay can be reduced using observation units $(18,19,32-35)$. It seems logical that application of the same evidence-based processes of care associated with the improved results in the emergency departments and observation units should be relevant in the inpatient setting. The reduced hospitalization rates and shorter durations of stay reported in observation units imply that inpatient admissions do not have the same prescribing methods, access to objective measures, frequency of reassessment, or problems with skill sets or adequacy of staffing.

\section{Summary}

There is compelling evidence that acute asthma remains a common, difficult problem to treat in emergency departments and after discharge. A collaborative and integrated approach to the continuum of asthma management is necessary to ensure patient safety and the best possible quality of life for people with this condition. This includes the appropriate use of objective assessment, standardization of acute treatment, adherence to sound discharge criteria, prescription of medications that relieve symptoms and control inflammation, access to asthma education, action plan review and close follow-up by primary care providers.

\section{REFERENCES}

1. Cates CJ. Comparison of holding chambers and nebulisers for beta-agonists in acute asthma (Cochrane Review). Issue 4. Oxford: Cochrane Library Update Software, 1998.

2. Plotnick LH, Ducharme FM. Should inhaled anticholinergics be added to beta2-agonists for treating acute childhood and adolescent asthma? A systematic review. BMJ 1998;317:971-7.

3. Stoodley RG, Aaron SD, Dales RE. The role of ipratropium bromide in the emergency management of acute asthma exacerbation: a metaanalysis of randomized clinical trials. Ann Emerg Med 1999;34:8-18.

4. Rowe BH, Travers AH, Holroyd BR, Kelly KD, Bota GW. Nebulized ipratropium bromide in acute pediatric asthma: does it reduce hospital admissions among children presenting to the emergency department? Ann Emerg Med 1999;34:75-85.

5. Rowe BH, Spooner CH, Ducharme FM, Bretzlaff JA, Bota GW. The effectiveness of corticosteroids in the treatment of acute exacerbations of asthma: a meta-analysis of their effect on relapse following acute assessment (Cochrane Review). Issue 4. Oxford: Cochrane Library Update Software, 1998.

6. Rowe BH, Spooner CH, Ducharme FM, Bretzlaff JA, Bota GW. Corticosteroids for preventing relapse following acute exacerbations of asthma. Cochrane Database Syst Rev 2000;2:CD000195.

7. Schuh S, Reisman J, Alshehri M, et al. A comparison of inhaled fluticasone and oral prednisone for children with severe acute asthma. N Engl J Med 2000;343:689-94.

8. Edmonds ML, Camargo CA, Pollack CV, Rowe BH. Early use of inhaled corticosteroids in the emergency department treatment of acute asthma (Cochrane Review). Cochrane Database Syst Rev 2000;3:CD002308.

9. Garrett J, Williams S, Wong C, Holdaway D. Treatment of acute asthmatic exacerbations with an increased dose of inhaled steroid. Arch Dis Child 1998;79:12-7.

10. Guttman A, Afilalo M, Colacone A, Kreisman H, Dankoff J, for the Asthma ED Study Group. The effects of combined intravenous and inhaled steroids (beclomethasone dipropionate) for the emergency treatment of acute asthma. Acad Emerg Med 1997;4:100-6.

11. Hamrick M, Chambliss ML. Combined oral and inhaled steroids for acute asthma. J Fam Pract 1999;48:657-8.

12. Rodrigo G, Rodrigo C. Inhaled flunisolide for acute severe asthma. Am J Respir Crit Care Med 1998;157:698-703.

13. Edmonds ML, Camargo CA, Saunders LD, Brenner BE, Rowe BH. Inhaled steroids in acute asthma following emergency department discharge (Cochrane Review). Cochrane Database Syst Rev 2000;3:CD002316. 
14. FitzGerald JM, Shragge D, Haddon J, et al. A randomized, controlled trial of high dose, inhaled budesonide versus oral prednisone in patients discharged from the emergency department following an acute asthma exacerbation. Can Respir J 2000;7:61-7.

15. Rowe BH, Bretzlaff JA, Bourdon C, Bota GW, Camargo CA Jr. Intravenous magnesium sulfate treatment for acute asthma in the emergency department: a systematic review of the literature. Ann Emerg Med 2000;36:181-90.

16. Parameswaran K, Belda J, Rowe BH. Addition of intravenous aminophylline to beta2-agonists in adults with acute asthma (Cochrane Review). Cochrane Database Syst Rev 2000;4:CD002742.

17. Carter ER, Webb CR, Moffitt DR. Evaluation of heliox in children hospitalized with acute severe asthma. A randomized crossover trial. Chest 1996;109:1256-61.

18. Emond SD, Woodruff PG, Lee EY, Singh AK, Camargo CA Jr. Effect of an emergency department asthma program on acute asthma care. Ann Emerg Med 1999;34:321-5.

19. Goldberg R, Chan L, Haley P, Harmata-Booth J, Bass G. Critical pathway for the emergency department management of acute asthma: effect on resource utilization. Ann Emerg Med 1998;31:562-7.

20. Bailey R, Weingarten S, Lewis M, Mohsenifar Z. Impact of clinical pathways and practice guidelines on the management of acute exacerbations of bronchial asthma. Chest 1998;113:28-33.

21. Strauss L, Hejal R, Galan G, Dixon L, McFadden ER Jr. Observations on the effects of aerosolized albuterol in acute asthma. Am J Respir Crit Care Med 1997; 155:454-8.

22. Shrestha M, Bidadi K, Gourlay S, Hayes J. Continuous vs intermittent albuterol, at high and low doses, in the treatment of severe acute asthma in adults. Chest 1996;110:42-7.

23. Qureshi F, Pestian J, Davis P, Zaritsky A. Effect of nebulized ipratropium on the hospitalization rates of children with asthma. N Engl J Med 1998;339:1030-5.

24. Barnett PL, Caputo GL, Baskin M, Kuppermann N. Intravenous versus oral corticosteroids in the management of acute asthma in children. Ann Emerg Med 1997;29:212-7.

25. Becker JM, Arora A, Scarfone RJ, et al. Oral versus intravenous corticosteroids in children hospitalized with asthma. J Allergy Clin Immunol 1999;103:586-90.

26. Rodrigo G, Rodrigo C. Corticosteroids in the emergency department therapy of acute adult asthma: an evidence-based evaluation. Chest 1999;116:285-95.

27. Rowe BH, Bretzlaff JA, Bourdon C, Bota GW, Camargo CA Jr. Magnesium sulfate for treating exacerbations of acute asthma in the emergency department. Cochrane Database Syst Rev 2000;2:CD001490.

28. Emerman CL, Woodruff PG, Cydulka RK, Gibbs MA, Pollack CV Jr, Camargo CA Jr, for the Multicenter Asthma Research Collaboration (MARC) investigators. Prospective multicenter study of relapse following treatment for acute asthma among adults presenting to the emergency department. Chest 1999;115:919-27.

29. Emerman CL, Cydulka RK, Crain EF, Rowe BH, Radeos MS, Camargo CA. Prospective multicenter study of relapse after treatment for acute asthma among children presenting to the emergency department. J Pediatr 2001;138:318-24.

30. Brenner BE, Chavda KK, Camargo CA Jr. Randomized trial of inhaled flunisolide versus placebo among asthmatic patients discharged from the emergency department. Ann Emerg Med 2000;36:417-26.

31. Rowe BH, Edmonds ML. Inhaled corticosteroids for acute asthma after emergency department discharge. Ann Emerg Med 2000;36:477-80.

32. Gouin S, Patel H. Utilization analysis of an observation unit for children with asthma. Pediatr Emerg Care 1999;15:79-83.

33. Rydman RJ, Isola ML, Roberts RR, et al. Emergency Department Observation Unit versus hospital inpatient care for a chronic asthmatic population: a randomized trial of health status outcome and cost. Med Care 1998;36:599-609.

34. McDermott MF, Murphy DG, Zalenski RJ, et al. A comparison between emergency diagnostic and treatment unit and inpatient care in the management of acute asthma. Arch Intern Med 1997;157:2055-62.

35. Gouin S, Macarthur C, Parkin PC, Schuh S. Effect of a pediatric observation unit on the rate of hospitalization for asthma. Ann Emerg Med 1997;29:218-22.

\section{IMPLEMENTATION OF GUIDELINES $\checkmark$ Mark FitzGerald, Dennis Bowie}

The role of guidelines in determining parameters for the management of medical conditions is well established. As the guideline process has evolved, the importance of an evidence-based format, and the role of guidelines in highlighting management decisions where there is only consensus, has been established (1). A much more important and challenging task is that of guideline implementation; this topic was recently reviewed comprehensively (2). A recent review in the United States to assess physician understanding and practice with regard to asthma guidelines found significant deficits (3). Although respiratory specialists scored better than generalists overall, all groups lacked an ability to assess disease severity.

In conjunction with the recent update of the Canadian Asthma Guidelines, there has been an increased effort to disseminate the guidelines and to make them locally accessible via the Internet (www.asthmaguidelines.com). In addition, a number of mailings highlighting the key components have been sent to physicians. A patient-oriented version of the guidelines has been developed and should be available soon.

Successful implementation of guidelines is a multifaceted process that is best achieved via local implementation by key opinion leaders (4). Interventions targeted to the time that physicians interact with patients (5) and educational interventions requiring active professional participation are more likely to be successful (6).

\section{REFERENCES}

1. Shaneyfelt TM, Mayo-Smith MF, Rothwangl J. Are guidelines following guidelines? The methodological quality of clinical practice guidelines in the peer-reviewed literature. JAMA 1999;281:1900-5.

2. Heffner J, ed. Translating guidelines into practice: implementation and physician behavior change. Chest 2000;118(2 Suppl):1S-73S.

3. Doerschug KC, Peterson MW, Dayton CS, Kline JN. Asthma guidelines: an assessment of physician understanding and practice. Am J Respir Crit Care Med 1999;159:1735-41.

4. Lomas J, Enkin M, Anderson GM, Hannah WJ, Vayda E, Singer J. Opinion leaders vs audit and feedback to implement practice guidelines. Delivery after previous cesarean section. JAMA 1991;265:2202-7.

5. Feder G, Griffiths C, Highton C, Eldridge S, Spence M, Southgate L. Do clinical guidelines introduced with practice based education improve care of asthmatic and diabetic patients? A randomised controlled trial in general practices in east London. BMJ 1995;311:1473-8.

6. Grimshaw J, Freemantle N, Wallace S, et al. Developing and implementing clinical practice guidelines. Qual Health Care 1995;4:55-64. 


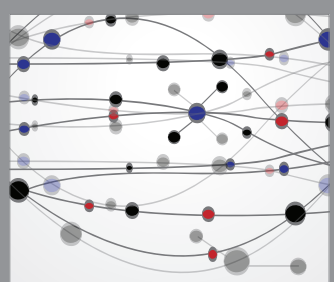

The Scientific World Journal
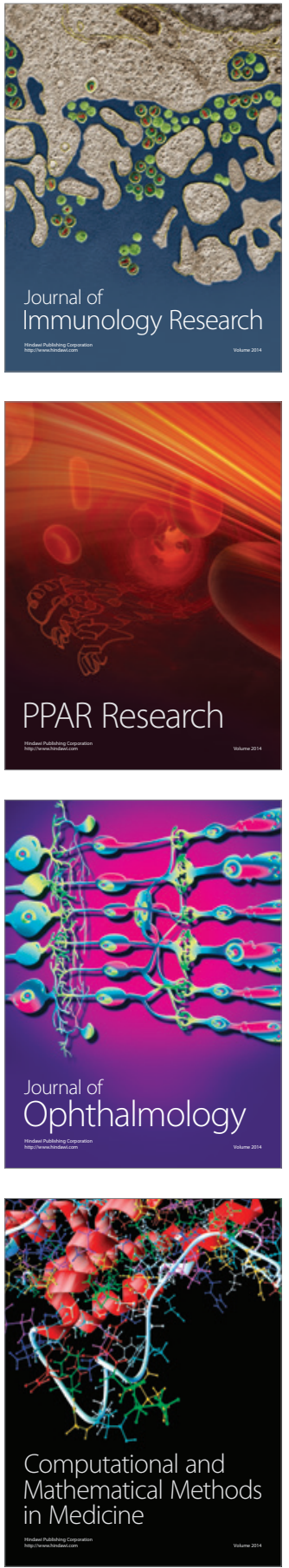

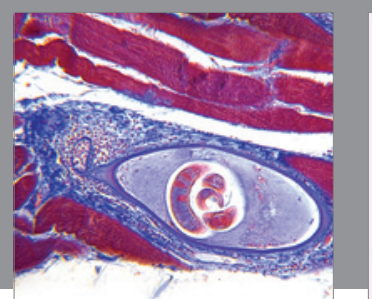

Gastroenterology Research and Practice

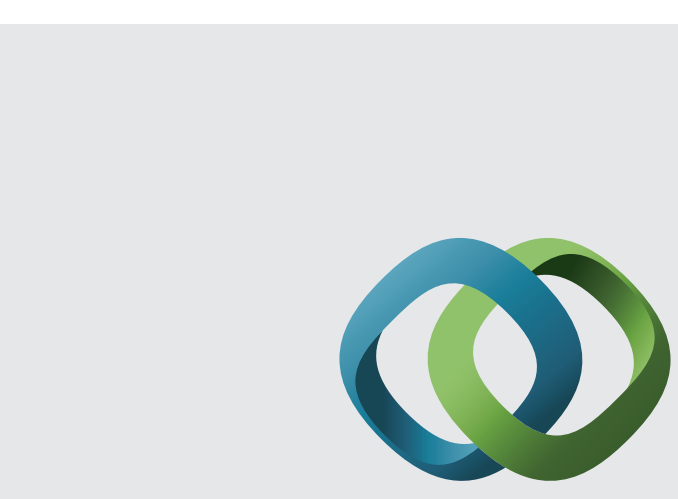

\section{Hindawi}

Submit your manuscripts at

http://www.hindawi.com
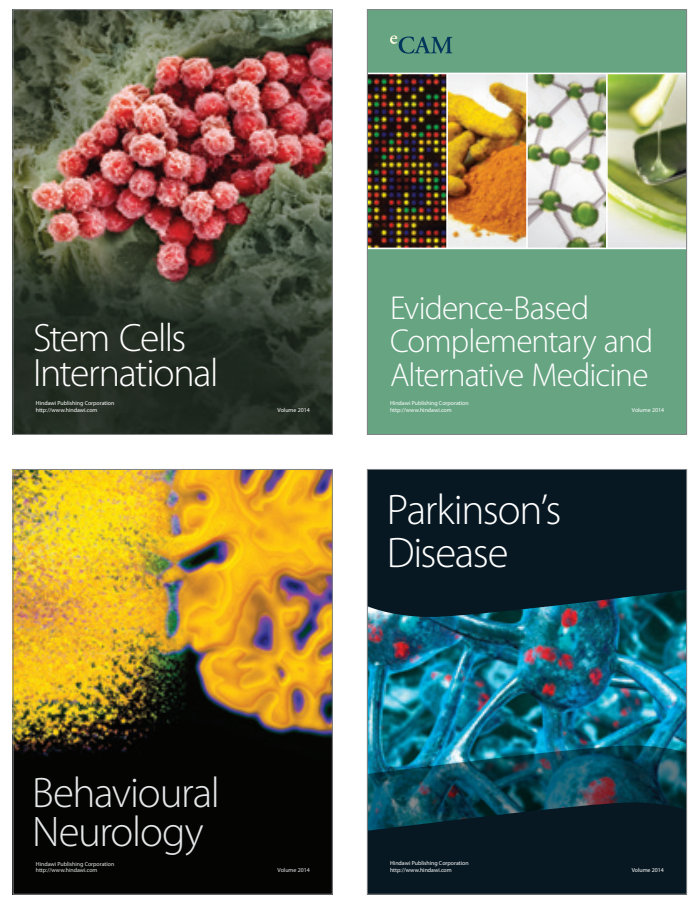
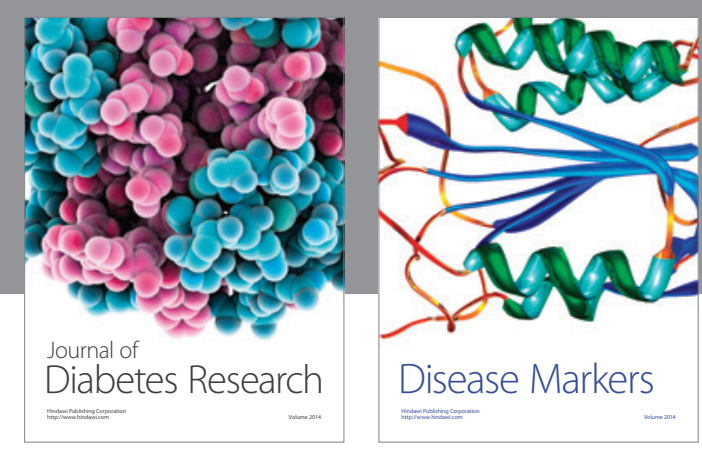

Disease Markers
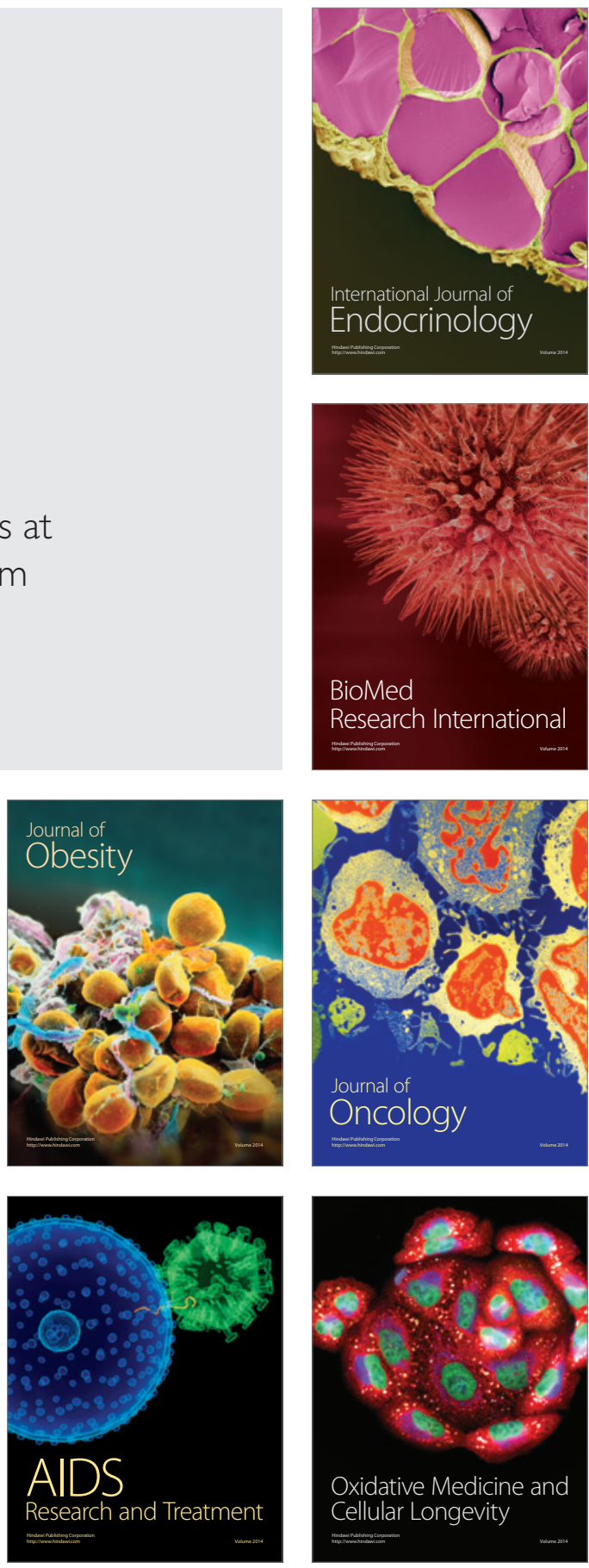